\title{
Reknitting communities: Rita Duffy's vital gestures
}

\author{
Hedwig Schwall
}

As textile is an apt metaphor for the complexities of human perception and of societal structures, it is not surprising that textile motifs have been central to the work of Rita Duffy. ${ }^{1}$ In Duffy's oeuvre, North and South, masculine and feminine, politics and economics, the conscious and unconscious, life and death drives, past and future, are the warp and woof of this life-embracing artist. Different items of textile (school uniforms, skirts, shirts, anoraks, handkerchiefs, sheets, mantles, wigs, cloth dolls and knitted dolls) have been a metaphor and a metonymy for her main concern: the question of how art - textile art - can set people free. This article highlights the importance of the textile items the artist herself selected for inclusion in this issue of RISE showing how each of them point at ways to move from a power system into one of agency, from fate to destiny. Each of the textile works are briefly situated in the context of other painters (Kahlo and Picasso, David and Chagall), writers (Parker and Morrissey, Enright and Tóibín) and thinkers (Bollas, Arendt, Santner, Mouffe, Rothberg). Time and again Duffy's textiles turn out to be linked to 'the good enough mother' and to women's solidarity, both of whom facilitate the child's passage from trauma to genera, developing from a negative past to a positive future in which an authentic self can be realized. Duffy's textile language will be discussed in six sections: (1) four drawings predating the textile items in this issue reflect how the mother enables the artist's disciplined imagination; (2) clothes belonging to 'martyrs' are so 'othered' that instead of holding the past they break narrow new moulds; (3) Cloth 1, Duffy's handkerchief of Bloody Sunday illustrate how reading genera is a 'seeing with the whole emotionality'; (4) this 'hankie' is further contested and contextualized in Duffy's collaboration with Muldoon; (5) the idea of the hankie and laundry extends into the veronica motif and into an understanding of Duffy's political art as a realization of Arendt's natality, which leads to (6) Duffy's most recent development of the Souvenir Shop method, where connectedness and humour are more articulated than ever and where the politics of culture involve multidirectional memory and economic participation.

\section{Freeing the self: conflict and play, dreams and education}

We start off with four drawings from the catalogue Banquet which Duffy made in the latter part of the 1990s; they contain, in a nutshell, all the elements that will be elaborated in the textile items she selected for this issue of RISE. Each of these works offers a portrait of the artist as a young girl who is looking for her own path in life. As Donald Winnicott and Christopher Bollas argue, a person can either not be bothered to find her own self, and from sheer inertia realize a false self in direct imitation of others, or she can choose to realize her own self which she can only find in conflict, i.e. facing her unconscious with its dark aspects. In the first case the person is swallowed by the reigning system of power and passively accepts her fate, in the second she actively chooses her destiny thanks to transitional objects which

\footnotetext{
${ }^{1}$ Though this article will focus on the textile motif in Rita Duffy's work I will not consider it as a cultural material. There is a magnificent body of critical literature on textile as cultural / art practice (e.g. Jessica Hemmings The Textile Reader or Penny Macbeth and Claire Barber's Outside: Activating Cloth to Enhance the Way We Live) but that aspect is beyond the scope of this essay.
} 
will help her to find an agency of her own. ${ }^{2}$ The 'activity' of this choice is something which happens in the child's earliest stage of life, which usually takes place in the maternal sphere. Of course the traditional mother also participates, indirectly, in the reigning culture, but at one remove, since she, traditionally, is relegated to the domestic sphere and so is not prominent in the more general political power structures.

In the Awakening Tryptichs I and /I the Duffy-like girl represented here is in school uniform, standing near a stairway and an open door, between her tall mother and a very small figure representing a Catholic school authority (Dominican). The diminutive size of the figures of authority in this series augments the importance of the mother whose down to earth preoccupations show her care as she is folding a bandage away or offering a coat. The girl's uniform has stiffened into an almost metal harness, indicating that she may have absorbed some of the institution's ethos; yet the girl remains closer to the mother's side, looking dreamily beyond the diminutive figures of power, seeming to feed on dreams which are filled with a shining lamb and flying fish in the picture somewhere beyond the open door. In the third part of the tryptich the male figures of authority have disappeared entirely and the girl is not wearing a uniform anymore; instead, she is literally (i.c. pictorially) in touch with her mother. This adult is a rich, much connoted figure: she is barefoot, in direct link with the earth, but also linked to openness, as she is always situated in this series next to an open door, stairs to go up and down, an open window. She wears working clothes, but her head gear, a towel worn in turban fashion, introduces an exotic touch. While she is working, she is dreaming: her gaze is elsewhere, beyond her occupation. Finally it is worth noticing she is using a tool with holes as if to indicate that she is carefully sieving the outer world. The daughter mirrors this attitude as she too is 'working' in her own way, also handling a tool with holes, a net with which she tries to catch the fish-like, phallic 'objects' which belong to the mother's aura: they interact with the mother and the things she is handling (i.c. the hub). The fact that these sperm-like forms are flying through the space of each of the drawings indicates they are of central importance. In these imaginative objectifications of the eros drive, we recognize Winnicott's 'intermediate area of experience, unchallenged in respect of its belonging to inner or external (shared) reality, constitut[ing]... the greater part of the infant's experience' and here elaborated in Duffy's autobiographical art.

Many psychoanalysts have thought up names for these mental images which here seem to be exuded or attracted by things (the hub in Awakening III, the door) by people (the mother in Awakening II and III, the priest in Awakening I \& II) or by the general atmosphere

\footnotetext{
${ }^{2}$ In The Evocative Object World Bollas points out that 'there is a particular urge to fashion a life, and this destiny drive is the ceaseless effort to select and use objects in order to give lived expression to one's true self' (87). Winnicott adds that of all 'objects' which help the infant find his self the 'transitional object' is the most important one: 'The transitional object and the transitional phenomena start each human being off with what will always be important for them, i.e. a neutral area of experience which will not be challenged' (Winnicott 12). To Winnicott the nature of this object is external (like the teddy bear which has to replace the mother and so help the baby to get through the anxiety of her absence) and so he distinguishes it from the 'internal object (which is a mental concept') Melanie Klein sees as a central component in the formation of the baby's psychological balance (Winnicott 9). Later Winnicott drops the question as to whether the object which helps the young child to transit a difficult period is interior or exterior: 'The intermediate area of experience, unchallenged in respect of its belonging to inner or eternal (shared) reality, constitutes the greater part of the infant's experience, and throughout life is retained in the intense experiencing that belongs to the arts and to religion and to imaginative living, and to creative scientific work' (14). It is this 'intense experiencing' we will follow as Rita Duffy's textile art changes over the last twenty years.
} 
(public life in Awakening $I$ and $I I$ ) and which allow for 'intense experiencing' within play. The analyst Bracha Ettinger finds a good definition for this kind of mental toy: 'The phallic and the matrixial objet $a$, like the objeu (Fédida) ... are not-yet-objects and not-any-more things, but are between things and objects'. ${ }^{3}$ Two things are interesting here, the matrixial realm and the nature of the 'object'. First, these fascinating mental 'objects' come into being in a borderspace which belongs to the 'good enough mother'. In Melanie Klein's terms this means a mother's attitude and ministrations which convey a balance between disciplining (frustration, 'weaning') and freedom, i.e. allowing the child to dream and play, to find the particular images which will form her deepest self, so she can develop her destiny. Second there is the nature of the 'object a' which is neither an object nor just an atmosphere but something in between, a kind of nodal point in an aura, or as Fédida calls it: an 'objeu' (playing on the homophonous nature between the French words objet and jeu (object and virtual reality of play). But Duffy's portrait of her youth does not stop by analyzing the fascinating aspects of the home atmosphere which she did not understand at the time, she also catches the eros drives in the image of eel-like fish, turning them, in Awakening III, into the matrixial playthings that they are: what Winnicott calls 'the initiation of experience' is here shown in its further process. ${ }^{4}$ The playful 'eels' are truly 'transitional' objects: after being caught in the girl's net they are processed in her glass jar, where they metamorphose into a human figure. So the drawing shows us the workings of the imagination which seeks to develop its personal idiom.

\footnotetext{
${ }^{3}$ Bracha L. Ettinger, The Matrixial Borderspace (Minneapolis/London: University of Minnesota Press, 2006 ), 55.

${ }^{4}$ D.W. Winnicott, Playing and Reality (New York: Routledge, 1989), 14.
} 


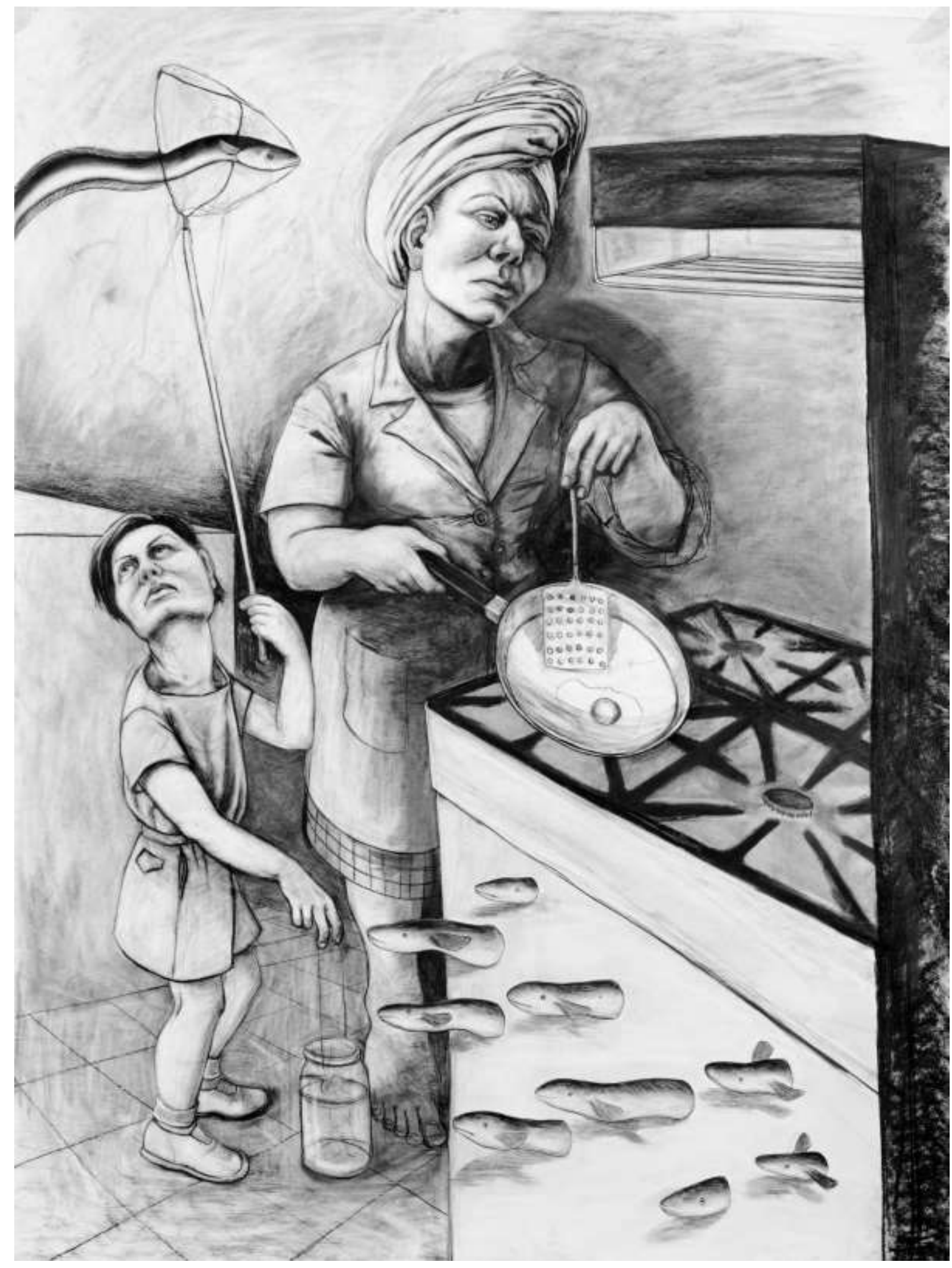

Rita Duffy, Awakening Tyrptich III (1996) 
Finding one's authentic self and realizing one's destiny is a tall order, but it is central to psychoanalysis, whether the Anglo-Saxon or the French kind. So, though this may complicate things, I briefly want to juxtapose all terms used by different analysts to mark the images which originate in childhood and 'will always be important'. ${ }^{5}$ While Duffy's fish are a clear manifestation of Winnicott's 'transitional objects' (as they inspire transition from animal to human content) but they equally correspond to Ettinger's matrixial objeux (playthings which can be caught, allowing the girl to emulate the mother as they both wield a tool to sieve the outer world with) and to Lacan's term of 'maternal imagoes', images from the motherly sphere which are fascinating, i.e. making the unconscious concentrate. When these maternal imagoes keep returning in the child's inner world and are processed, repeating themselves in variation, he calls them phantasms; they metamorphose as the physical, mental and emotional faculties develop. ${ }^{6}$ Bollas calls them 'genera' because they keep generating forms which contain unconscious affects which may later be articulated further into verbal precision. It is interesting in Bollas' system that it also allows the situating of trauma as the opposite of genera, in a way which is in line with Cathy Caruth's definition. To her trauma is something which stops mental growth, it possesses a person and therein overrules his articulating faculties, it paralyzes and fragments the searching self, sabotaging development and freezing all psychic energy. Instead of allowing for the space necessary for play and curiosity, traumatizing objects and images keep a 'surprising literality and nonsymbolic nature of traumatic dreams and flashbacks'.7

As we saw, the phallic fish which are flying through the girl's world are positive, representations of the eros drive; but when we look at Drumcree Lily, the drawing which directly precedes the Awakening series in Banquet, they are absent. There is no mother figure here, only an opposition between the tiny male figure in the front of the flower pot and the very tall girl behind it. This opposition is very complex. The figure in the front is diminutive, male, completely clad in Orange Order symbols (bowler hat, tie, suit, shoes, sash); though he stands in a defensive position in front of the dark pot, he neither looks at the lily himself nor does he allow anybody to approach the huge symbol which towers over him. The other half of the picture is filled with a girl who wears neither a uniform nor shoes: like most mother figures in Duffy's oeuvre she is bare-footed. She has just crossed a border, leaving a darkness behind her to look directly and closely at the lily with great curiosity. While the man is the epitome of Orange order culture, the girl is the epitome of nature: her skirt is a grass skirt, or that of a dancer. The basic opposition permeating all previous aspects is that the older masculine figure is stopping while the feminine younger one is starting. This is interesting as it seems to depict the two trends that make up the human unconscious: the life or eros drives and the death drives. According to Jacques Lacan, every person has to come to terms with these two forces which rule a person's emotions, temperament, decisions - in short, her overall personality: 'The distinction between the life drive and the death drive ... manifests

\footnotetext{
${ }^{5}$ These images may be relevant to seeing the big developing lines in any artist, as they are bound to work with central motifs they vary on.

${ }^{6}$ For the full explanation of this type of images see Hedwig Schwall, 'Towards a new grammar of interiority: James Ramsay's circuitous way To the Lighthouse'. Grammar, usage and discourse, eds. Lieven Vandelanotte, Wout Van Praet and Lieselotte Brems, English Text Construction 10:2 (2017): 323-344.

${ }^{7}$ Cathy Caruth, 'Introduction', Trauma, Explorations in memory, ed. Cathy Caruth (Baltimore/London: The Johns Hopkins University Press, 1995), 3-12, 5.
} 
two aspects of the drive'. ${ }^{8}$ They are of prime importance as 'the drives at work in the individual's body' are the ones which 'create ... value and significance'. ${ }^{9}$ Moyaert further tackles the complicated issue of distinguishing between life and death drives and basically says that the death drives bring about 'a blind, nonfunctional, and repetitive movement' which 'pressurize[s] the vital forces'. ${ }^{10}$ The life drives, on the other hand, make one see things anew, they are multifunctional and varying and make for an upbeat personality. In short, the former are constrictive drives while the latter are constructive. ${ }^{11}$ It is also significant that both drives bring about a different kind of repetition. The one originating in the death drives is an imprisoning movement: "If this repetition, to which Freud fixes the label "daemonic," is not counteracted and inhibited, it transforms any content whatsoever into a claustrophobic and uncanny reality'..$^{12} 13$ The repetition of the life drives is enabling, one step in the process of self-articulation. Freud illustrates this with children's games which are 'directly pleasurable for the child because, by means of the game, he gains mastery over the situation. Here, repetition has a reassuring function: the pleasure principle and the well-being of the ego are capable of directly profiting from it'. ${ }^{14}$ In other words, the children's play helps them to articulate or 'discharge' what is preoccupying them even though they do not really understand what the game is about. This is exactly what we see in Awakening Tryptich III: the girl is fascinated by the phallic fish, but she somehow learns to catch and develop them (in the glass jar the eels have turned into a human figure). Through (repeated) play the girl becomes more familiar with the challenges of the eros drive. 'In this way, repetition leads to the binding of unbound energy to representations that allow the mind and body to move' ${ }^{15}$ So the girl catches spermlike (transforming) forms in the aura of her mother who is frying eggs. So this mother-daughter interaction offers a condensed, harmonious representation of the mystery of sexuality.

Interestingly, the death drive is more often connected with culture than with nature. Lacan, who usually defines a 'communal code' of a culture as 'the symbolic order', observes that closed communities tend to suffer from the death drive as they repeat themselves to death. He notices that it is 'simply the fundamental tendency of the symbolic order to produce repetition; the death instinct is the ... mask of the symbolic order' ${ }^{16}$ So he warns cultures about constrictive behaviour which leads to a claustrophobic outlook of its participants; in short, if the negative spiral of the death drives a culture it turns into a vulture.

In the four drawings under scrutiny, the death drives seem to be pictured in the small, uniformed figures of the Orange Order man and the two monks. All three are thickly clad in

\footnotetext{
8 Jacques Lacan, quoted in Dylan Evans, An Introductory Dictionary of Lacanian Psychoanalysis (Hove \& New York: Brunner-Routledge, 1996), 33.

${ }^{9}$ Paul Moyaert, 'The Death Drive and the Nucleus of the Ego. An Introduction to Freudian Metaphysics', The Southern Journal of Philosophy, Spindel Supplement 51 (2013): 94-119, 101.

${ }^{10}$ Moyaert 97.

${ }^{11}$ As we will see later, the death drives can further be distinguished in the oppressive and the excessive ones, or the stagnating and the maniacal mechanism.

12 Moyaert 103.

${ }^{13}$ The fact that every single person has his/her own fight to wage to keep the balance between life and death drives is clearly illustrated in Kilroy's The Devil I Know when the protagonist explains how he has to fight his alcoholism: 'The pint... these are not mannerisms I picked up from others, but ones that are so inherently, ineluctably mine that it is my life's work to break their hold on me' (18).

14 Moyaert 105.

15 Deleuze quoted in Moyaert 106.

${ }^{16}$ Lacan quoted in Evans 32.
} 
their uniform; the Orange man is brandishing a sword, the man in Dominican 'habit' has a gaunt face and a worried look at the eels. Contrary to these people who seem to want to lead (the monks) or to forbid (the Orange man) the girl is, in Drumcree Lily, Awakening I and II, always clearly in conflict with herself. In the first drawing she steps from a black background into the light of the lily; in Awakening I she steps from the obscure stairs to the open door, and in Awakening II again she opens a door to move from the domestic realm to a wider one. All pictures together seem to illustrate W.B. Yeats's famous dictum 'We make out of the quarrel with others, rhetoric, but of the quarrel with ourselves, poetry'. ${ }^{17}$ Indeed, it is the quarrel with the self which makes the girl see the lily in all its poetic beauty, and the lamb in all its light, while the official 'defenders' of those symbols who seem not in conflict with themselves do not see the poetic appeal of these traditional symbols any more.

Yet learning to distinguish between one's real and one's false self, the authentic and the mimetic self, is, though of vital importance, no simple business. This is why it is a problem on which many works of art and literature focus. Two examples, one from drama in the North and one from fiction in the South, will illustrate how distinguishing between imitation and authenticity, between power and agency, requires a radical self-questioning. In Stewart Parker's play, Northern Star, the protagonist, Henry Joy McCracken, leader of the United Irishmen at the end of the eighteenth century, warns both his contemporaries and the audience that they might not be as free as they think:

'Citizens of Belfast - you rehearse all of your chosen parts and you play them with the utmost zeal - except that maybe they're really playing you. Think about it. They costume themselves in your flesh and bones, borrow your voice, strike your poses, and at the end they move on'. ${ }^{18}$

In the same article on 'Performing Belfast' Stefanie Lehner shows how McCracken raises

questions of agency and power: are Belfast's citizens mere puppets, their chosen roles their puppet masters, thus taking on an identity of their own? ... This notion that individual actors no longer have agency and flexibility over their roles, suggests their congealed nature'.$^{19} 20$

The same question, namely how can a person develop his authentic self when pressurized by a culture's death drives, and one's own? is asked in a context of the Republic. In The Devil I Know, the novel in which Claire Kilroy criticizes the way in which the Celtic Tiger seems to induce a sense of greed in people, the protagonist wonders who he really is:

it is one of the many gestures that make me question whether I know myself, or whether I even am myself, and not some studied automaton copied from some other studied automaton, ad infinitum with nothing at the centre'. ${ }^{21}$

\footnotetext{
${ }^{17}$ W.B. Yeats, 'Per Amica Silentia Lunae', Mythologies (New York: Macmillan/Collier Books, 1969), 331.

${ }^{18}$ Stewart Parker, Northern Star, quoted in Stefanie Lehner, 'Performing Belfast: Stewart Parker's Northern Star (1984) and Pentecost (1987)', Boundaries, Passages, Transitions. Essays in Irish Literature, Culture and Politics in Honour of Werner Huber, ed. Hedwig Schwall (Trier: Wissenschaftlicher Verlag Trier, 2018); 41-52, 42.

${ }^{19}$ Parker, Northern Star quoted in Lehner 42.

${ }^{20}$ Interestingly, Rita Duffy has a painting of McCracken's Jacket (2004) which Fionna Barber links to Henry Joy McCracken, one of the leaders of the United Irishmen, who united both Protestants and Catholics. (Barber, 'An Iceberg's Collison with History: Some recent work by Rita Duffy', n.p.).

${ }^{21}$ Claire Kilroy, The Devil I Know (London: Faber \& Faber, 2012), 18.
} 
If one is in the grip of a powerful mentality this may gradually grab and wrap the subject for whom the new attitude is like a 'habit', something which dresses the mind in all its operations. Contemporary political theorists like Chantal Mouffe and Michael Rothberg have interesting concepts to help one find 'the right distance' from one's own culture. Mouffe distinguishes between 'agonism' and 'antagonism', whereby the former would denote 'the quarrel with ourselves' while the latter focuses on 'the quarrel with others'; Rothberg refers to 'multidirectional memory', a way to open one's past to a wider (and self-elucidating) 'transcultural remembrance' which would not compound but break 'competitive memory'. ${ }^{22}$ This is exactly what Duffy's art wants to do: to redress the mind, starting with her own, as this is the only way to authentically redress the public debate. More specifically, in the four pre2000 drawings under scrutiny the symbols of power (sash and sword, school and basilica, Protestant and Catholic uniforms holding up Protestant and Catholic lilies) are reduced while the symbols of agency are enlarged: it is the 'objeux', the playthings of the mind, the flying fish, representatives of the eros powers which will renew and deepen people's 'view' on things.

But of course Duffy too feels wrapped in the symbols of her own culture, only the obstacles will fuel her into an exploration of alternatives. Like Frida Kahlo she portrays herself as the young woman who is hemmed in by circumstances. Unlike Kahlo's restrictions which (in her youth) were mainly physical, Duffy's are cultural-political, that is, her young women are pressed into a mould by a whole symbolic system which tends to divide and rule. That this symbolic order is a masculine power system could be gleaned from the fact that in the tryptich the girl starts off with strong masculine features, but gradually, going from Awakening Tryptich I to III, she becomes more feminine. In the three next self-portraits we will discuss (with focus on Dolmen (1997)), the masculine and feminine cultures are more strikingly combined to show the artist's predicament. More specifically, the masculine constricting uniformity is in strong contrast with the feminine playfulness. Once more, the portrait of the artist as a young woman is one in conflict.

\footnotetext{
${ }^{22}$ Michael Rothberg, 'From Gaza to Warsaw: Mapping Multidirectional Memory', Criticism 53.4 (2011): 523-48, 523.
} 


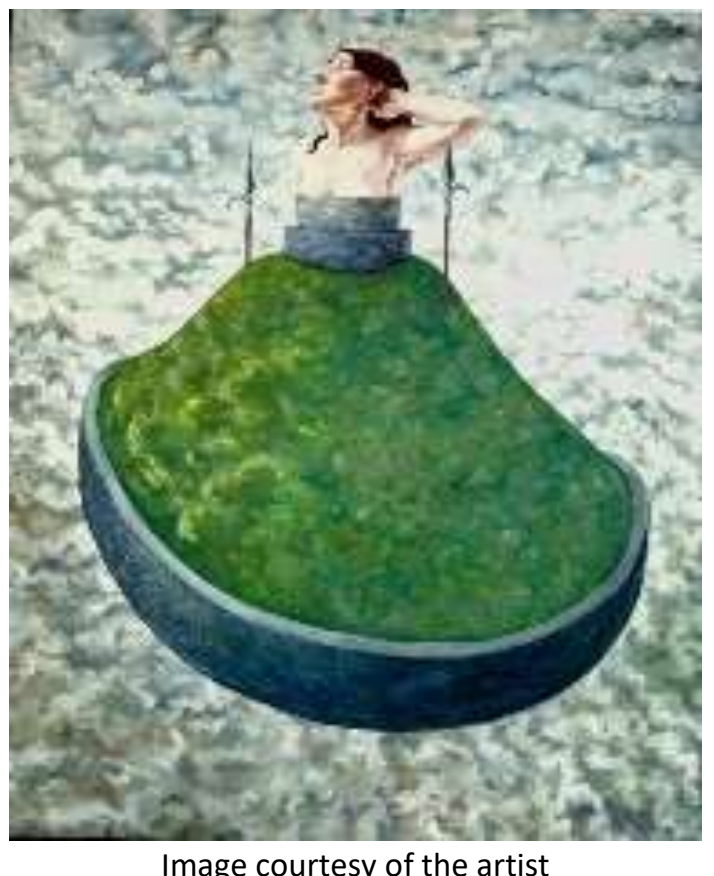

Dolmen is, in Duffy's oeuvre, a strongly (i)conic work. The green 'dress' looks like the communal system that imprisons her; this impression is underscored by the wall-like rim both at bottom and the top of the 'fortification'. Yet in the top part we find a woman who opens up to the sky in an elegant gesture which tilts her face up to the light and holds her ear, as if she wants to hear an alternative voice. In Duffy's variations on this theme, like Coronet (1996) or Crown cake (1996), both printed in Banquet, the contrasts are even stronger as the bottom half is formed by an aggressive structure with watchtowers while the top part, showing feminine underwear, suggests intimacy and creativity, with a woman who either arranges her hair or puts a crown on it. So from early on, Duffy's autobiographical paintings show that the artist is a figure in conflict, in agony even, rooted in a certain culture while striving towards an openness which is different and therefore richer. Though in Dolmen the central woman is stuck in the green fortress and hedged in by spears, her surrender is to the sky, the clouds, to an open, floating way of life. In this painting it seems even that art can be so strong that the whole, firm architectural construction is but a dress which can be lifted up into the air and set floating. Indeed, the cloudy background is not just behind the figure but also underneath it. So all these early paintings by Rita Duffy have one thing in common: a life drive, so strong that it can both acknowledge the cultural divisions and overcome them. So she offers the perfect illustration of the eros drive, 'a force that... both in the common sense understanding of life, as well as in the work of Bergson, is the notion of a driving, upward-tending force, [one]... that, instead of being arrested by obstacles, expands and diversifies itself by means of them' (Moyaert 95, my emphasis).

\section{Relics as palimpsests: accredited and accruing}

For this issue, Rita Duffy chose two representations of garments which belonged to politically active persons, Mairead Farrell and James Connolly; but both are treated as palimpsests and so are metamorphosed, history written over by later histories, accruing much more than their original symbolism (and, a fortiori, so much more than their functionality). The first one is called Relic (2002). This word refers to a trace from the past, either as something which was left behind, or as something to be venerated. In a Catholic context, a relic refers to a saint, and 
it was believed that a relic could cure, as the saintly presence was believed to work directly on the body. The cure even had a magic aspect to it (albeit a paradoxical one): if you had a relic from St Apollonia, who was reputed to have been tortured by having all her teeth drawn, your toothache would be cured; if your relic was connected with St Lucia, whose eyes were taken out, your eyesore would improve. Here however, the opposite is the case: the garment 'resonate[s] with a sense of "otherness"' as Rita Duffy puts it in her own commentary. ${ }^{23}$ It belonged to an IRA volunteer who stayed in Armagh Women's prison, and though this was nowhere spelled out in the painting Duffy's representation of the anorak was so fascinating to some vandalizing intruder in her studio that he wrote the letters UVF on it. Subsequently the artist left these letters as another trace in the underpaint to make it a layered political painting both in the literal (or pictorial) and the metaphorical sense of the world. But again Duffy's ecumenical colour symbolism turns something negative (the vandal's intrusion) into something positive. Though the anorak consists of variations of green, orange and white, the white part is very thin, so that the variegated green is directly next to the orange, which makes for a thick, warm lining of the green surface. Thus the colour scheme suggests that an IRA-UVF proximity can be realized in this work of art. As both the layers of the paint and the closeness of the colours point the way forward into a non-sectarian future, this 'relic' is more a beacon for a future than a reference to the past, and so may be a secular relic, charged with life drives.

In the title of the second garment, Connolly's shirt (2015), the original wearer's name has been kept, yet here too we have a palimpsest of histories as two layers have been added to the shirt; first, that of the bloodstain (connected to the aftermath of the Easter Rising), then that of the little green-orange-white houses (the Celtic Tiger years and their aftermath). Before we go into their meaning it is important to notice that Duffy compares this textile relic to the condensed layeredness of 'Agnes Richter's jacket' ${ }^{24}$ Richter's straitjacket was radically 'othered' in its functionality when this psychiatric patient translated her psychological pain into singularly beautiful stitching, puzzling psychiatrists and fascinating art critics, developing her own idiom of pain. ${ }^{25}$ But Connolly's shirt is also a relic and a paradox as it combines opposites. The first contrast in this piece of textile art is between the 'banal striped everydayness of Connolly's shirt' and the bloodstain, indicating that the man was a simple working-man, but one who risked his life for socialism and solidarity. The bloodstain, a trace of his execution at the hands of an oppressive power, remains an accusation of that constrictive system, but not only in the merciless British oppression of that time: a second history superimposed on this painted shirt is that of the boom of 'housing estates', metonymy for the greed which seeped into the mentality in the Republic during the Celtic Tiger Years. Like Yeats in 'September 1913' Duffy wonders whether this maniacal investing in housing has not killed the idealism symbolized in this shirt, because even after the post-Tiger depression many people have not come to their senses and still try to add the million to the billion. So, as

\footnotetext{
${ }^{23}$ Rita Duffy, 'Cloth', Review of Irish Studies in Europe 2.1 (2018): 46-56, 52.

24 Duffy, 'Cloth' 48.

${ }^{25}$ A similar phenomenon is shown in Muldoon's famous poem 'Anseo' in the character of a student with a revolutionary name, Joseph Mary Plunkett Ward, who had been sent out by the Master 'To weigh up for himself and cut / A stick with which he would be beaten.' He then turns his tool of torture into an aesthetic object which helps him through the period of punishment: a 'hazel-wand / He had whittled down to a whiplash, / Its twist of red and yellow lacquers/ Sanded and polished,/ And altogether so delicately wrought / That he had engraved his initials on it' (Poems 1968-1998 83-84). Only, this poem's protagonist was not successful in his (an)aesthetic, since he ended up acting as militarily as his teachers. In other words, Muldoon shows it takes more stamina than one thinks to escape a mimetic following of one's cultural codes.
} 
Duffy has moments fearing that, as men were born to grab and spend Connolly's Ireland's come to an end, she wanted to borrow the actual shirt of Connolly to make it the centre piece of the Shirt Factory project in Derry (in 2013) where she hoped it would fuel a discussion reviving the man's socialist ideals. It is a pity that the National Museum which houses the shirt did not let it go to 'play away'. Be that as it may, both 'relics', the anorak and the shirt, are seen as a possible cure, one against the sores of sectarianism in the North, the other against the money-mindedness of the Celtic Tiger mentality in the South. Interestingly, each relic is supposed to counteract a different manifestation of the death drive: while the first must combat stagnation ('conservative and stubborn forces that resist change and that cause the body's movements and activities to stagnate'), the second should help to call a halt to maniacal action ('production of antiproductivity'). ${ }^{26}$ Indeed as many post-Tiger films and novels indicate, housing estates are built which house next to no one (as in the short film Foxes) and which make no one happy, neither the few who live there nor those who, building and pricing beyond proportion enriched themselves beyond all proportion, losing all sense of solidarity and co-humanity. ${ }^{27}$

\section{Cloth 1 or the white handkerchief: passage to seeing with 'the whole emotionality'}

If the previous section showed how painting 'relics' could point a political way forward, Cloth 1 (2006 published in Cloth, a catalogue from 2008) shows us again something of Duffy's own inner movement forward. Hankies are strewn all over the artist's work and so form a central motif, their varying representations giving us some further insight into the formation of Duffy's idiom. We find hankies without colour, in light pencil drawings in Banquet; in The essential gesture they are called "Paxies", held by a feminine arm and referring to 'a sign of peace in a child's street games'; in Cloth they return in the form Rita Duffy selected for this issue. As we hope to show in this section Cloth 1 is another perfect illustration of a transitional object (so a phantasm or genera), being a representation of the mechanics of Duffy's representation. This implies that the image is supposed to show us how the 'agon', the struggle of her perception works, how genera help the artist to enlarge and deepen her seeing. The motif originated in Duffy's early youth, when black-and-white television impregnated the image on the twelve-year-old of Father Daly, a 'man of the cloth' (as Muldoon observes), pulled this improvised 'flag' from his pocket to wave the international sign of ultimate appeal for safe passage on behalf of the thirteen men shot dead by the British forces on January 1972, and of those who were carrying them.

In Cloth 1 the white hankie is a very poetic painting in that it is both a metonymy (selection) and a metaphor (condensation). Like all metonymies it is a figure built on a relationship of proximity, i.c. referring to people and things connected to the tragic events on Bloody Sunday. Here the people who waved it or needed it are left out, which means that this

\footnotetext{
${ }^{26}$ Moyaert 94

${ }^{27}$ Striking examples are the figure of the entrepreneur 'Pokey Burke' in Donal Ryan's The Spinning Heart or Tristram in Claire Kilroy's The Devil I Know. In Ryan's story 'Pokey' employed the local workforce without paying their social security while they were building housing estates which remain unfinished and only house two sad individuals. When his malpractice is revealed he flees leaving a devastated community and his family, ashamed of their son's dealings. Kilroy's Tristram St Laurence, Thirteenth Earl of Howth (25), bets away his whole family's (cultural) inheritance and ends up being left by all his so-called friends. In Foxes the alienating force of the desolate housing estate is so strong that the female partner of the couple becomes more and more animalistic until she morphs into a fox.
} 
metonymy is more specifically a pars pro toto, as it only selects the piece of textile, the ultimate request for passage. In its colouring too this painting is a pars pro toto: in this painting Duffy hammers her usual greens, oranges and whites into a murky density which mainly serves to highlight the contrast with the white hankie, thus echoing the original image on the black and white TV (as well as the press photos of that time) which impregnated themselves on her vision. In this aspect, Cloth 1 is Duffy's version of Guernica: in both cases innocent citizens were killed by armed forces, a shocking event which both artists learned from the media, and both retain a very restricted colour scheme, cutting out all anecdotal or predictable details to filter out and highlight the visibility of power gone wrong. And Duffy goes even further in her abstraction: though she is often seen as 'very much within the figurative, narrative tradition' (Hutchinson 193), here she is more restrained than Picasso whose Guernica combined many triangles to suggest the sharp contrasts in the conflict. In Cloth 1, Duffy condenses her issues in the 'small triangle of white cloth'. In her article 'Rita Duffy's Unquiet Relics' Fionna Barber takes this painting as an example of how 'The isolation of the crumpled fabric of Cloth 1' shows a 'paring-down of form and composition [which] belies a depth of meaning'. ${ }^{28} 29$

It is this depth we want to go into, and it brings us to the question of the metaphorical power of Cloth 1. A metaphor is not built on a relation of proximity but of similarity, and one striking similarity here is that between the political and the personal: the hankie signals not just the (historical) need of passage in an armed context but also the need for constant passage in a personal, psychological context. Indeed when we recall that Winnicott defined the transitional object as one which 'will always be important ... [as] a neutral area of experience which will not be challenged', Duffy's handkerchief is exactly that: not just a historical echo of Father Daly's request for passage but also a universal call for passage and a sign of her own passage to further artistic development. ${ }^{30}$ And the passage is especially striking, in the sense that the handkerchief is a motif originating from a traumatizing context, yet it will turn into a genera, as it will generate the next project, and many after. If the handkerchief is simultaneously a trauma, a transitional object and a genera, it must be a very complex metaphor, an image with many hinges.

Like most long-lasting images the handkerchief is a paradoxical image: in its Derrydian context it symbolizes the inequality between the armed forces who shot unarmed citizens as they marched for equality. The scandal of such blatant injustice catapulted some people (like Mairead Farrell) into political action, while it challenged the artist Rita Duffy to represent this event. In Cloth 1 she managed to condense the 'fear and sectarianism, a constant slow drip battle' which has been her biotope 'for over 30 years'. But while this dark biotope forms the background of the painting, the hankie in the foreground refers back to an 'objeu', an object used in a children's play, more specifically as a 'Paxie': a sign to ask for a moment of peace, of safe passage. This 'transitional object' from a positive context, linked with many other autobiographical paintings of textile (Duffy painted clothes, shoes and bags she owned as a kind of autopictography) form a consistent strand in the artist's imagination, like Bollas'

\footnotetext{
${ }^{28}$ Fionna Barber, 'Rita Duffy's Unquiet Relics', The Canadian Journal of Irish Studies 37.1-2 (2011): 36-47, 38.

${ }^{29}$ On a micro-level one might observe that the hankie combines several triangles which, allowing for a wide parallel, recalls Géricault's The Raft of the Medusa: there too, helpless people are left behind to die by the ruling classes, and some are waving types of cloth to be rescued. But again, Duffy is more restrained than the romantic painter: this hankie is not even waved, it seems to have fallen; it seems somehow forgotten, yet held up by the darkness; it seems simultaneously dropped and draped.

${ }^{30}$ Winnicott 12.
} 
genera: 'Any self will organize a psychic structure around desire and its history that will not only drive further curiosity but also sponsor important mental realisations, or epiphanies, that develop the self'. ${ }^{31}$ The objects or images which exert such fascination on a subject are of course deeply personal symbols, not prescribed by one's culture. They are signalled by one's own unconscious, often not understood but merely felt, and recognized merely in their significance, their weight. Genera are not things one possesses: 'rather the object is pursued in order to surrender to it as a medium that alters the self'. ${ }^{32}$ They

crystallize time into a space where subject and object appear to achieve an intimate rendezvous. ... once experienced, these occasions can sponsor a profound sense of gratitude in the subject that may lead him into a lifelong quest for some other re-acquaintance with the aesthetic object. $^{33} 34$

'[P]sychic genera [gather]... impressions into one area of the self's psychic life - in order to assemble the mental material of what would ultimately be a new perspective on himself, his past, and his future'. ${ }^{35}$ Thanks to the phantasmata the subject can weave its own mental images and so form his own psychic DNA which Freud described as 'diverse logical threads emanating from, or drawing towards, psychic nuclei'; 'this arrangement has a dynamic character'. ${ }^{36}$

So the phantasm is a kind of object with an aura, an 'objeu' which engages the whole unconscious, (and considering the beneficial dynamic character, especially the life forces), and because it is so rich and deep-reaching it is impossible to completely consciously articulate why the object is so fascinating. Hence Jean Laplanche calls the phantasm the 'enigmatic signifier' ${ }^{37}$ Moyaert too stressed that it is the unconscious which can detect a phantasm and assess it. Bollas speaks of genera as 'the spirit of the object as the hand of fate' ${ }^{38}$ except the fact that the artist keeps reinterpreting these central yet elusive signifiers means that they do not lead to fate but to destiny. ${ }^{39}$ In order to see these elusive signifiers at all the person who goes into the "agon", the challenge of herself, will need to move into a special kind of seeing. In what follows I will show how Eric Santner, in his essay 'Was heisst Schauen?' goes about

\footnotetext{
${ }^{31}$ Christopher Bollas, The Evocative Object World (London: Routledge, 2009), 28, my emphasis.

${ }^{32}$ Christopher Bollas, The Christopher Bollas Reader (London/New York: Routledge, 2011), 2, my emphasis.

${ }^{33}$ Christopher Bollas, The Shadow of the Object. Psychoanalysis of the Unthought Known (New York: Columbia University Press, 1987), 31.

${ }^{34}$ A classic example would be the beam from the lighthouse which appealed to Mrs Ramsay in To the Lighthouse; it is an image of which she somehow feels that it sums her up. She identifies with it and when she notices it she feels reassured that she is right, that she is following her deepest vocation and living her unique life. In short, when a subject recognizes its phantasms it means that that person can integrate the different aspects of his/her being and realize his/her destiny in relative independence of the powers that be.

35 Bollas, Evocative Object World 29.

${ }^{36}$ Bollas, Evocative Object World 31.

${ }^{37}$ Eric Santner, On the Psychotheology of Everyday Life. Reflections on Freud and Rosenzweig (Chicago: Chicago University Press, 2001), 33.

${ }^{38}$ Bollas, The Shadow of the Object 30.

${ }^{39}$ Moses met 'the hand of fate' in the burning bush which remained unburned. It remained an enigmatic signifier, one which made its importance felt so strongly, that Moses sensed that something sacred, something secret, was taking place. It gave him his vocation but no certainty; at some point he broke the tablets of the law and had to get them again; also he never reached the Promised Land.
} 
this question, then I illustrate it with Sinéad Morrissey's poem 'In Belfast' and finally with some additional paintings by Rita Duffy.

Finding a handkerchief to metamorphose political trauma into the transitional object of the paxies and even into a genera is what we expect from an artist often inspired by fabrics, clothes and habits: she often defuses situations and recharge them with positive challenges (as in the 'relics' of the previous section). But what about the murky background, which takes most of the painting? This reminds of Jacques-Louis David's painting Death of Marat. Of course Duffy is far from a neoclassicist, she is even stylistically the opposite, but in Cloth 1 she seems to be doing precisely what Eric Santner sees happening in the 'scumbled surface' which fills 'the complete upper half of David's painting' and which he considers 'the single most extraordinary feature of the picture'. ${ }^{40}$ He interprets the dark half as the place not where something is represented, but representation itself. It is the medium in which gestation, is going on, 'painting as pure activity... detached from any representational task'. ${ }^{41}$ Simultaneously, Santner interprets the murky upper half of The Death of Marat as the still invisible start of 'the shift from the King's to the people's sovereignty' 42 and he sees that darkness as an appeal for the reintroduction of 'the charms, the stuff of enchantment' 'into the fabric of everyday life, that they in some quasi-literal way get under the skin of the modern subject $^{\prime 43}$ and he ends his essay on David in 'Was heisst Schauen?' pleading for an art which appeals to our whole emotionality, of the unconscious: 'it is only because of the persistence of something like aesthetic "aura" or "charisma" that we can resist the deep pull of skepticism endemic to the reigning forms of rationality. ${ }^{44}$ This analysis completely chimes in with Duffy's programme: the background compounds her usual references to orange and green ideologies and synthesizes them even more than in the previous paintings, thus letting the whirr of colours make their own atmosphere. Yet there may seem an indication of a shift towards more passage, more interaction and more democracy as it looks as if the gold-orangey lines in the middle support the hankie, which is also pulled up by the light spots behind it. ${ }^{45}$

In Cloth 1 Duffy gives her own version of what seeing is to her. Like in the Awakening series, we clearly see how she lets the life drives hold the brush as the orangey and black lines pull this piece of textile up, giving full swing to 'a driving, upward-tending force'. ${ }^{46}$ Refusing rhetorics Duffy instead always makes the detour over dreams, to let the 'whole emotionality' speak, to let 'the persistence of something like aesthetic "aura" or "charisma"' win over 'the deep pull of skepticism'. In this we find a striking parallel in the poetry of Sinéad Morrissey, Belfast's former and first Poet Laureate, in whose work the motif of visionary, compassionate seeing is a constant feature. It is interesting to see how in her poem 'In Belfast' she combines the first part of the poem which focuses on power while the second celebrates the roots of all agency, the unconscious. The metonymies of power in part I ('Royal avenue', 'Albert Bridge' and of course 'Victoria Regina steering ... her intense provinces, / a ballast of copper and

\footnotetext{
40 Santner, Everyday Life 93.

${ }^{41}$ T.J. Clark quoted in Santner, The Royal Remains. The People's Two Bodies and the Endgames of Sovereignty

(Chicago and London: The University of Chicago Press, 2011), 92-3.

42 Santner, Royal Remains 98.

43 Santner Royal Remains 99.

${ }^{44}$ Santner, Royal Remains 117.

${ }^{45}$ Unlike David who made the painting shortly after Marat's actual death this version of Duffy's Handkerchief dates from 2006, 34 years after Bloody Sunday and 8 years after the Good Friday Agreement.

${ }^{46}$ Moyaert 95.
} 
gravitas') contrast with Part II where the speaker delves into her own darkness after she has returned to the city where she will find a deeper reality in 'sleep'. It is only in the counterweight of the depths of the unconscious that she will be able to accommodate 'this history's dent and fracture // splitting the atmosphere'. Indeed the speaker moves to a moment of complete kenosis, the emptying of narcissism: 'And what I have been given / is a delicate unravelling of wishes / that leaves the future unspoken and the past / unencountered and unaccounted for'. ${ }^{47}$ This radical resourcing seems an equivalent of Duffy's barefoot women who get in touch with Life in order to avoid being trapped in the 'mimetic desire' 48 that sectarian societies suffer so much from. Yet at the end power and agency find each other when Belfast is held together by the textile metaphor: 'This city weaves itself so intimately'. Everyone and everything is presented as a weaving of associations, connotations, emotions, experiences, memories and beyond-memories. ${ }^{49}$ It is striking how Morrissey's poetry and Duffy's paintings run parallel, not only in their concept of seeing with one's whole emotionality but also by their treatment of motifs. While Morrissey's 'In Belfast' highlights and then deflates the statue of Victoria Regina, Duffy's The essential gesture paints a whole series of 'Victoria Regina', big white statues peaking into a Marian blue sky, to then juxtapose her with one of her famous icebergs. Both Belfast-born artists criticize a perception which has not made the detour of dreams; ${ }^{50}$ both seem to replace power with a 'sovereignty' which can only be reached by people who are 'so foreign' to themselves that they lose their surplus narcissism and get into their own proper 'agon'. And both would side with Lacan's plea to replace a power which is fed by 'connaissance' (French for 'knowledge'), by commitment which originates in 'co-naissance' (French for co-birth). Not hierarchy but solidarity is key.

This acknowledgement that truth comes from cooperation and co-exploration rather than from knowledge and power is underscored by the fact that Cloth 1 is not only floating and lifted up by the background, but it also seems to be painted in 3-D, with its furthest tip reaching out to the spectator, like Caravaggio's Disciples of Emmaus who, in lively Baroque fashion, draw the visitor into the scene as one's outstretched hand and the other's white-clad elbow are poking the spectator in the face, including us in the imaginative exercise that the painting presents. ${ }^{51}$ In what follows we will see that Rita Duffy's art will reach out even further.

\footnotetext{
${ }^{47}$ Sinéad Morrissey, Between Here and There (Manchester: Carcanet, 2002), 13.

48 'Mimetic desire' is a term borrowed from René Girard as he explains 'The Scapegoat' mechanism. As soon as there is a difficulty (natural or man-made disaster) people find some unloved minority to ascribe the causes of the disaster to them, so they can direct their anger at them and punish them rather than wonder about their own part in the events (The Scapegoat 128, 134, 166).

${ }^{49}$ In his famous Künstlerroman Malte Laurids Brigge R.M. Rilke points out making the detour over the unconscious is essential in the making of proper, layered, lasting art. This means that one has to forget about one's old habits and old communal systems to 'learn to see' in a personal way. This also means one has to learn to feel things, which is in itself a complex event. A poem, he says, starts by having emotions; these need to be further articulated, which leads to experiences. These in turn have to link up with childhood events and the 'difficult transformations' they brought. Further these memories have to sink into forgetfulness, into the unconscious, to become part of our bodies, 'our very blood' and our personalities, to come 'into glance and gesture'; 'only then can it happen that in some very rare hour the first word of a poem arises in their midst and goes forth from them' (19-20).

${ }^{50}$ As Vikki Bell put it: Duffy's 'art-works make something familiar appear as if at a distance, as if it had travelled far to meet us anew, to tell of that journey.' ('The Poetry of Cloth: Painting, Potentiality and Politics' Cloth, 8).

51 'To stand before these canvases is to receive an invitation to consider one's own existence, one's own wayof-being, through theirs' (Bell 8).
} 


\section{Cloth 2: The Splendours of the purple: power, mortality, revenge, confusion}

It is not surprising that Morrissey and Rilke may prove helpful in illustrating how Rita Duffy's art comes into being: this artist is often inspired by poetry. Wesley Hutchinson highlights the way in which Duffy heightens the effect of Seamus Heaney's poem 'The Act of Union' in her work Territory (1996) by cutting out the explicit political references while intensifying 'an impression of intense claustrophobia as the viewer looks in on two self-contained, parallel worlds in habited by the same grotesquely deformed figures' ${ }^{\prime}{ }^{52}$

In Cloth, A Visual and Verbal Collaboration by Rita Duffy \& Paul Muldoon (2007) ${ }^{53}$, Duffy practices her 'literal ... "poetics of space"' again, but as Muldoon is a co-artist the effect is different. ${ }^{54}$ Indeed, while Cloth 1 removed all human figures, even all narrative and a fortiori all explicit references to history, Muldoon reinserts historical details. In this collaboration two features stand out: first, there are many direct references both to victims and murderers in specific attacks, so the effects of power and mortality are highlighted. No wonder that in this cooperation the death drives are shown to either make 'stubborn forces' making a society 'stagnate', or they are shown to be outright destructive and producing 'antiproductivity'. 55 Second, the imitative patterns of behaviour inherent in a revenge culture are outstanding which makes for a portrait of a society riddled with ironies.

This is clearly illustrated in Muldoon's reference to Denis Mullan, a Catholic who was shot by the UVF in his house, a murder he describes ironically as 'Arterial blood. The splendour of the purple' (36). On the opposite page Rita Duffy's painting of a Mantle (2006) looks like a bishop's outfit in many shades of purple, carmine and vermillion, fusing with the 'arterial red' of its background. The juxtaposition of text and image complicates Muldoon's critique of this murderous Protestant ethos as it suggests that both the power of Protestant paramilitaries and that of the Catholic Church seeks its symbolism in blood sacrifice. This confusion is further compounded by irony when, two pages down, Cloth 2 (2006) appears, another version of the handkerchief we know from the Bloody Sunday context, only now the handkerchief is juxtaposed to a text about the Kingsmills massacre in which Muldoon reports how ten Protestant linen workers (who were very protective of their Catholic co-worker) were murdered by Catholics. His comment: 'the splendour of the purple yet again'. ${ }^{56}$ Again, the irony plays on many levels. First, there is the discrepancy between fact and verbal representation: murder is never splendid. Second, the 'splendour' of the Catholic Church is stained as its power structures either work the wrong way (if they instigated the killing), or don't work at all (as Catholic paramilitaries use that name in vain to prolong a murdering culture). But third, and, most important of all, the murdering by Protestants and Catholics mirror each other, so all are victims of mimetic power structures; the tit-for-tat mechanism is the effect of uncurbed death drives which lead to an impasse. This is underscored by the fact that Muldoon's text specifies that 'I was drinking in a pub in Linenhall Street' when he heard

\footnotetext{
52 Wesley Hutchinson, 'Rita Duffy, Variations on the Theme of Separation', Etudes irlandaises 30.1 (2005): 193201, 194.

${ }^{53}$ This book project was part of 'the Interrogating Contested Spaces in Post-Conflict Society project' and connected with the exhibition 'Cuchulain Comforted' by Rita Duffy and Paul Muldoon.

${ }^{54}$ Hutchinson 195.

55 Moyaert 94.

${ }^{56}$ Paul Muldoon, 'Anseo', Poems 1968-1998 (London: Faber and Faber, 2001), 83-84, 40.
} 
of 'the gunning down of 10 Protestant linen workers at Kingsmills'. ${ }^{57}$ Linen is everywhere, forming the filaments of society, but its structures are constrictive and confusing. ${ }^{58}$

But as we saw before, imitation, mimesis, does not only work between enemies, it also affects one's own ranks. We see this in Muldoon's anecdote of the time when he was an 'altar boy' 'marching out' 'on a Sunday morning' with 'a lace-fringed linen surplice' over his red dress - he, too, participated in the splendor of the Church while his mother and sister were in the congregation wearing their version of their 'glad rags'. ${ }^{59}$

Apart from using colour metaphors to represent the complexities of their society, Muldoon and Duffy use a humour-infused 'cloth criticism' to loosen up the static tit-for-tat mechanism. This humour is, once more, based on a comic discrepancy between word and image, between the literal and the metaphorical. So Muldoon points out that a member of the local family of linen barons was knowns by some as 'a big wig', by others as "'Handkerchief" Cowdy'. ${ }^{60}$ This is illustrated on the adjacent page by Duffy's painting Big Wig (2007), a painting of nothing but a wig without a (critical) head under it: it is a culture of parts without a 'totum': there are signs of power but no agency. The authority has no head, let alone compassion. This fits in with Duffy's other 'cloth criticism' as in her 'Justus Series', starched collars made in England, neatly sewn wigs, all floating emptily in the air, like shirts which are not even stuffed, merely carried off by high airs. All personality, particularity, has evaporated.

Like Relic (which was also selected for the Muldoon cooperation), many other pieces of clothing in Cloth are suspended, which may be a metaphor for the artists' invitation to people to suspend judgment and 'Interrogat[e] ... Contested Spaces in Post-Conflict Society project'. As Megan Johnson, the MCAC Manager who enabled this initiative, states, the aim of this collaboration is to 'create dialogue', engaging 'with the concepts of compassion and empathy'. ${ }^{61}$ What Muldoon and Duffy show in this book is that 'contest' in a sectarian atmosphere is no more than an indication of the negative spiral set off by the death drives. Yet in its original meaning a con-test invited the eros drives, as in a fair play sporting competition where you give the best of yourself in order to challenge the other to do the same, and so raise human standards. But before that can happen, power must change into agency, mortality into natality, revenge into redemption and confusion into compassion, which is what Rita Duffy will do in her next big motif, that of laundry.

\section{The splendours of the people: agency, natality, redemption, compassion}

Raising womanly standards, or rather lines, is what Duffy does in her laundry motif which appears the next year, in 2009. It allows her to move from 'the splendour of the purple', this darkly ironic reference to parallel worlds of sectarian murder, back to the basics of the

\footnotetext{
${ }^{57}$ Muldoon 40.

${ }^{58}$ This confusion is underscored by Muldoon's striking observation that 'the workers, thinking this was a Protestant death squad, protected the one Catholic in their midst. It turned out this was a Catholic death squad. Toe the line. Line, from the Latin linum, "flax".' (Cloth 40)

59 Muldoon 26.

${ }^{60}$ Muldoon 38.

${ }^{61}$ Megan Johnston, 'Interrogating Contested Spaces in Post-Conflict Society. Collaboration in Verbal and Visual', Cloth. A Visual and Verbal Collaboration by Rita Duffy \& Paul Muldoon (Portadown: Millennium Court Arts Centre), 2007, 3.
} 
mothers' world which I would call 'the splendours of the people', represented in laundry motif. Like the handkerchief, it is a motif which recurs, and the fact that it appears in different art 'genres' makes it extra interesting. We will go into two works, one a drawing, the other an installation.

The first, simply titled Laundry (2006), is huge, so that the figures really come to life. Duffy calls it 'a shadowy composition', and indeed this is underscored not only by the medium of charcoal but also by the content: all contacts are indirect, but vital. In order to illustrate this I will concentrate on two women who characterize the interaction between them all: the woman on the right whose face is barely visible through the sheet and the central figure, further identified in Duffy's comment as her mother.

This picture brings several kinds of women together: most are barefooted, but one in the background wears a hat. They may represent several social classes, but as this is only vaguely suggested the differences are not significant. Most important is that these women all interact. The figure in the foreground is wearing a skirt of which Duffy highlights the hand grenade pattern. ${ }^{62}$ This reminds us of Dolmen, Coronet and Crown Cake, where the girls were dressed by the 'siege mentality', illustrating that, like Muldoon who enjoyed his own 'glad rags' as an altar boy, a communal system is easily adopted by children. Yet here it is the interaction between women which is more articulated as this hand grenade pattern is echoed in the women's laundry baskets. Interestingly the basket's patterns are the negative of the grenade, as if the girl has the potential to explode while the other women contain. The woman on the left is even directly linked to the violence as her basket contains heads. She even manages to hold this container of violence, but only while looking away from it, as does the girl with the grenade dress. A third girl, deeper in the composition, again reflects the grenade girl both in form and action, as she too only looks at the head basket sideways, while holding up a support pole together with the mother figure, the tallest one in the centre. So, the thrice repeated pattern of acknowledging violence sideways seems to indicate that the women take a certain distance from the violence in their midst. But what with the fourth woman in the foreground on the right? She is the most shadowy of all, as her face is filtered by the sheet she is hanging up together with the 'dynamic' girl. In the laundry motif, which Duffy interprets as the washing away of a dark past in a womanly collaboration in sympathy, the sheets repeat the 'proferred handkerchief' which 'Duffy has termed "the essential gesture", 'a sign of compassion' which Fionna Barber further connects with 'an earlier iconography of handkerchiefs in the associations with St. Veronica' ${ }^{63}$

This brings us to the relic par excellence, the 'veronica', or 'vera icon', the 'true image'. It refers to the legend of a woman whose compassion with the suffering of Jesus made her wipe his face with a cloth, upon which she found the face had miraculously imprinted itself on the cloth. It was the only authentic portrait in the world, as it was 'acheiropoeietes', not made by human hands: the object (Jesus' face) had imprinted itself without any medium on the cloth. And because it was not only the perfect human portrait, but also that of God, it was said to be miraculous and healing those who touched it. No wonder this image has been a central phantasm of Western art: it combines all kinds of paradoxes, the human and the divine, direct presence and representation, subject and object, nature and culture. No wonder that

\footnotetext{
62 Duffy, 'Cloth' 47.

${ }^{63}$ Duffy, The Essential Gesture. Recent Works by Rita Duffy. Catalogue, March 2005 n.p.
} 
champions of Catholic belief such as El Greco, Zurbaran, Claude Mellan and others thought this was the model to imitate. Especially Mellan's The Veil of St Veronica (1649) exudes the belief that art can bring divine presence back: he had etched the incredibly intricate portrait in one single line, without ever lifting the burin. Moreover, this near-miraculous masterly feat was done in preparation of 1650, a holy year; he must have hoped that his art would heal, or at least stun spectators into a belief in miracles. But of course working in a twenty-first century mentality and in Northern Ireland, Duffy's Veronica is different. When we look more closely at the 'shadowy' woman in Laundry we actually see two, maybe even three faces, two of which are partly effaced, shaded over. Yet we can still see them, as in the stills of an animation film where one figure is drawn in slightly different positions. Moreover, we see not only an imperfect picture of a woman's face but also hands. So instead of the classic veronica, which shows the perfect portrait of one divine man, made without hands, a perfect rendering with a healing force, we here see a 'moving' face in 'a shadowy composition', a woman whose hands are vital in a cleansing of 'shared stains and familiar trauma', sharing the sheet-hanging with another girl, in com-passion (literally, sharing the work of laundering and of mourning, dealing with the results of violence). Here, the healing does not come from some metaphysical miraculous power but simply from solidarity with other women; and instead of maintaining the image of sacrifice, as the veronica did (which was said not to fade), these women make a point of washing stains and move on.

With all these differences with the original one might wonder whether the veronica legend still appeals at all to Irish artists and authors of the twenty-first century. Going by Anne Enright's 2007 Booker-Prize winning The Gathering the answer is yes. That this is a 'shadowy' book is clear from its opening where the protagonist, Veronica, sets the tone:

I would like to write down what happened in my grandmother's house the summer I was eight or nine, but I am not sure if it really did happen. I need to bear witness to an uncertain event. I feel it roaring inside me - this thing that may not have taken place. I don't even know what name to put on it. ${ }^{64}$

While Duffy's women daily face the results of sectarian violence, Enright's Veronica needs to come to terms with her brother's suicide which is linked to the huge scale of abuse of children in Catholic institutions in the Republic. In order to articulate this trauma Veronica engages in a 'scriptotherapy'65. So it seems that in times where individuals become aware of the fact that trauma is endemic to certain power systems, the veronica motif is (again, paradoxically) an appropriate model for a process in which to test one's radical honesty against an uncritical mimetic behaviour. And it is significant for our century that neither Duffy nor Enright feels entitled to offer a finished portrait, let alone a perfect one: it is all a matter of process, a complex sieving of emotions in which our skin, clothes, body image, gestural interaction ... all

\footnotetext{
${ }^{64}$ Anne Enright, The Gathering (London: Jonathan Cape, 2007), 1.

${ }^{65}$ Maybe one should call it a (s)cryptotherapy, as writers and artists often write things which lead them to unexpected, new perspectives. As they follow the lead of their language, what was previously cryptic to them is translated from the unconscious to their conscious self. Writers like Enright, Colum McCann, John Banville, Claire Kilroy and many others repeatedly state in interviews that writing is self-exploration. As we hear from Enright: 'I am very impatient with the real. I find that language's ability, ... language strains towards metaphor. And I follow on. And then sometimes I might make the metaphor radical, like I have an angel knock on the door instead of saying he looked like an angel. So it is linguistically determined, my relationship with the real.' (Interview with Schwall, 22)
} 
help to filter the world into ever-developing truths. In Duffy's Laundry as in Enright's The Gathering (a gathering of insights and of redeeming links with the family members, especially the mother) the women protagonists do not pretend to "know" (Lacan's connaissance) but they acknowledge the need for interaction to be reborn (co-naissance).

The second woman then, even more central in Laundry, is the 'mother figure' with the harp-like hair do. This symbol from the South reminds us that the artist's mother was born in the Republic, yet she came to live in the Troubles. She is depicted in an enterprising gesture, yet as a woman of balance, setting up a pole to support the washing lines which is in counterweight to the other pole; together they from a $\mathrm{V}$ of peace. Likewise, the pole will link earth and air, allowing the laundry to be lifted in the wind, so the stains will disappear in the breath of history, which offers a past from which to learn how to live a better future (as the 'relics' did). Interestingly, the Duffy-like figure is helping to hold the mother's pole; as in the Awakening Tryptichs both are in interaction. Once more it is the inclusive symbolism of the mother who combines South and North, earth and sky, who will enable the daughter to translate the traumas of her youth into genera. ${ }^{66}$

The work Laundry Day in Derry (2013) is even more a matter of 'the simple splendours of the people' in the sense that it is an installation in William Street, an important 'lieu de mémoire' where at least two sad events are commemorated: the Bloody Sunday killings and the huge unemployment wave that hit Derry when the shirt factories were closed.

Yet Duffy's work seems to move always further away from trauma into the ever-more articulated hope of genera. The dark background of Cloth 1 and the shadowy drawing make way for an installation in which the sky is the limit; the installation's textile is rippling and (un)furling in real wind under which real people are invited to walk into the picture and literally look up to the sky and the shirts, washed by so many women. So many clean slates - clean shirts. And if ever there was a work of art that was not acheiropoietes, it is this one: it is all about women's hands, about work which seems ephemeral, yet maybe is not. Duffy's installation was commissioned to celebrate Derry being a Cultural Capital in 2013. This brings us to the question of how the politics of art are realized here, how Rita Duffy's work can be said to be political.

For a possible answer to that we turn to Hannah Arendt who distinguishes three kinds of being in The Human Condition: that of labour, work and action. Labour is 'the activity which corresponds to the biological process of the human body, ... metabolism, and eventual decay ... bound to the vital necessities' ${ }^{67}$ A synonym of labour could be 'care', and this installation is an ode to that aspect of life as laundrying is the 'metabolism' of textile: its dirt has to be removed and flushed away, until the shirts' wear and tear will turn them into rags when they can be recycled for some other use, like dusting, polishing: all this is labour, maintenance. Second there is 'Work'. This is slightly more 'creative' as it 'provides an "artificial" world of

\footnotetext{
${ }^{66}$ In an interview quoted by Adele Dalsimer and Vera Kreilkamp Rita Duffy talks about 'her mother's desire to affirm an Irish background while raising children in a Protestant area in Northern Ireland' (209). The flitting birds may once more link Duffy's work with poetry. The artist observed that the actual birds that flew around her head while she was making this drawing inspired her so much that she drew them into her work. Thus she echoes the openness to nature of the (pre-partition) Irish monks who integrated delightful nature into their work as in 'The Blackbird at Belfast Lough'.

${ }^{67}$ Hannah Arendt, The Human Condition, Second Edition (Chicago: University of Chicago Press, 1989 ), 7.
} 
things... Within its borders each individual life is housed, while this world itself is meant to outlast and transcend them all' ${ }^{68}$ A synonym of work is 'craft': the women who made shirts in the Derry factories are celebrated here, as they made shirts to meet the needs of many different individuals. Third, Arendt distinguishes 'Action', which

corresponds to the human condition of plurality, to the fact that men, not Man, live on the earth and inhabit the world. While all aspects of the human condition are somehow related to politics, this plurality is specifically the condition--not only the conditio sine qua non, but the conditio per quam - of all political life. ${ }^{69}$

In short, to Arendt politics is essentially interaction, not between groups but between individuals, belonging to different genders. Indeed gender plays an important role in this interaction, as Arendt takes the model of her interaction from the very beginning of the Bible, where God saw that he needed two humans in order to have a 'human condition': 'Male and female created He them'. ${ }^{70}$ In this way, Arendt defines the unique, singular self in a preDerridian way, namely, in his difference from any other. In other words, political action is that which enables each person to find his or her unique difference from the next person: 'Plurality is the condition of human action because we are all the same, that is, human, in such a way that nobody is ever the same as anyone else who ever lived, lives, or will live' ${ }^{71}$ This almost Kantian 'sapere aude', dare to be yourself, is the precondition of any individual to find her/his own genera, her own unique trail of stones which leads one from physical birth to psychological birth. Realizing this transition is what Arendt calls 'natality': you are really born as a person when you come into your own. This is what we already saw in Duffy's Awakening series: the child leaves the mother and the home to be e-ducated, which literally means to be 'led out' of one realm into another; one of the realms is the school, the other her private world of the phantasms. ${ }^{72}$ On the level of political theories Rothberg, Mouffe and the 'social cosmopolitans' raise the same plea, calling for a 'cosmopolitan memory' to feed the agon in the self and in the group:

depoliticizing the historical context and privileging compassion over socio-political passions, cosmopolitan memory leaves the field open for a novel type of memory work that is able to manipulate passions and emotions in order to construct a collective sense of 'sameness'. ${ }^{73}$

\footnotetext{
${ }^{68}$ Arendt 7.

${ }^{69}$ Arendt 7.

${ }^{70}$ Genesis quoted in Arendt 7.

${ }^{71}$ Arendt 7.

72 The image of the 'trail of stones' comes from the fairy tale of Tom Thumb, a story which basically conveys the need of being led out of your original circle. Like someone who tries to read genera, Tom Thumb realizes he does not understand much but he pays all the more attention to striking details and changes in atmosphere. This enables him to leave the small house of his parents, visit the scary home of the giant, but he escapes and returns enriching the home situation. Morrissey's poem 'In Belfast' shows the same pattern: she found herself at home only after having made the detour round other cultures (like Germany, Japan, New Zealand...). The poem is part of the volume Between Here and There which again highlights the need to leave one's habitual life in order to 'other' the self which opens new perspectives. In Portrait of the Artist as a Young Man Stephen Daedalus too thinks along these lines when he tells a friend he can only find his own roots if he leaves the country for a while: 'Told him the shortest way to Tara was via Holyhead'(Portrait of the Artist Chapter 5.4, 250).

${ }^{73}$ Anna Cento Bull and Hans Lauge Hansen, 'On agonistic memory', Memory Studies 9:4 (2016): 390-404, 400.
} 
Indeed Arendt observes that in order to be 'political' one has to be aware of one's difference with the neigbour; only being aware of the plurality of people and perspectives allows for politics proper. This is why Duffy also portrays the dark powers in herself and in society - as she said about her Thaw Project: 'It's time to come out of denial and confront what has sunk us' $^{74}$ Indeed, in the Thaw Project, the Titanic functions as a metaphor of the Troubles: like some leading politicians and paramilitary groups, the officers in charge of that beautiful ship refused to pay proper attention to the nature of an iceberg; they deemed themselves invincible, like wigs without a head. In a striking performance Duffy had an iceberg towed all the way to Belfast as an inverted pilgrimage which should change the inhabitants' emotions: as an objective correlative of the unconscious, which is mainly invisible, it must be acknowledged; and as the installation gradually melts this is an objective correlative, an image of the ritual all need, to let their fear melt and face their own 'underwater self'. When a person reaches this point of familiarity with their deeper self they can seriously say that they act according to their own agency, rather than being a puppet on the strings of some power system.

The next thing Laundry Day in Derry illustrates is how, in Arendt, the women's natality and their readiness for the small, daily sacrifice is opposite to the men's ethos of mortality and metaphysics. We saw that laundry, to Duffy, is an image of women washing the stains of history, but that does not mean they simply ignore the past. This installation 'creates the condition for remembrance, that is, for history'; it is necessary to see the patterns of negative repetition before one can radically renew. ${ }^{75}$ But art looks both ways, so the past of murder and lost jobs is connected to a wind-enlivened, multicoloured enterprise. The installation differs from the usual kinds of bunting in either Union Jacks or (Irish) Tricolours decorating a street: while those masculine flags dress some ideology, delineating it from others in a defensive way, these feminine signs of life are varied, combining shirts for men, women and children and thus representing their care for each member of the household. These washing lines do not defend, they welcome: they do not delineate but they link, connecting all the women whose care enables individuals, in their own humble ways, to be educated and explore. And it is this enabling of unicity which is the essence of what Arendt calls natality:

Labor and work, as well as action, are also rooted in natality in so far as they have the task to provide and preserve the world for ... the constant influx of newcomers who are born into the world as strangers. ... the new beginning inherent in birth can make itself felt in the world only because the newcomer possesses the capacity of beginning something anew, that is, of acting, $^{.76}$

It is exactly what happened in the 'matrixial' care of the Awakening series; but also in Laundry Day in Derry, as Duffy comments:

the installation was a wishful washing away of past traumas ... Laundry Day for Derry had a celebratory feel, a rebirthing of sorts. This collective of shirts caught the breeze and made men and women look up to the sky, recognizing at some deeper intuitive level perhaps that essential human gesture, to begin our lives again each day. ${ }^{77}$

\footnotetext{
${ }^{74}$ Duffy quoted in Hutchinson 200.

${ }^{75}$ Arendt 8-9.

${ }^{76}$ Arendt 9.

77 Duffy, 'Cloth' 46, my emphasis.
} 
Duffy's shirt-flags replace nationality with natality, making space for individuals who each have the 'capacity of beginning something anew'. This has been Duffy's 'policy' within her art but also in the public sphere: when the artist was president of the Royal Ulster Academy of the Arts (in 2008) she exercised this enabling attitude in that function. Starting up an exhibition in a building 'which quite possibly contains the stained and grey soul' of her beloved Belfast she wanted to 'change the perception of the RUA and provide something exciting and dynamic in the visual arts'. ${ }^{78}$ Against 'the dull lack of belief that has taken root in the organisation' 'I wanted to do the best I could dream of, believing that we get what we are capable of imagining. ...let's pull together ... reposition... this organization as a force for change, cohesion and positivity in the visual arts'. ${ }^{79}$

Arendt further qualifies natality as opposed to metaphysical thought: 'natality, and not mortality, may be the central category of political, as distinguished from metaphysical thought'. ${ }^{80}$ Not the heroic end but the potentiality of a new beginning is what Arendt and Duffy focus on, the chance and challenge each new-born brings, 'each capable of new initiatives that may interrupt or divert the chains of events'. This sheer ability to innovate is what Arendt admires, 'the one miracle-working faculty of man' ${ }^{81}$ Not statics or 'statistical laws and their probability' count but that humans are 'able to perform what is infinitely improbable.' Natality can bring a miracle not referring to metaphysics but to a solidarity which allows humans to be 'the same' in that all are unique and equal: politics to Arendt is a matter of being 'a distinct and unique being among equals'.82 This paradigm of 'immanent transcendence' is something Arendt has in common with Freud, Santner, Rosenzweig et al who turn away from 'an Elsewhere that would be higher, more real'. ${ }^{83}$ This ties in with Rita Duffy's installations which oppose transcendent models of thought fed by heroic deaths, instead she celebrates the immanent transcendence of daily care. Again, this outlook would be shared by most contemporary Irish artists and writers. Indeed going back to Parker's play Northern Star we find that the hero's partner challenges his status of national hero interpreting it as 'irresponsible egotism':

[Y]ou're more in love with that rope than you are with me and the child ... [...] The love of your family isn't enough. My love isn't enough. You want the love of the whole future world and heaven besides. All right, go ahead, let them love you to death, let them paint you in forty shades of green on some godforsaken gable-end! ${ }^{84}$

In Toibin's The Testament of Mary this shift in paradigms is at the heart of the novella, in which the author makes Mary, the most 'transcendentalized' woman of Catholicism, challenge the metaphysical framework gospel writers and theologians (like St John and St Paul) developed, using masculine violence to impose their paradigm on her and eventually on the world at large. In this novella, Mary reflects on how she witnessed Jesus' trial: 'Everyone else knew that something was being played out for the sake of the future, that nothing mattered now except the killing'. ${ }^{85}$ As she misses this 'metaphysical consolation', the experience is all the more

\footnotetext{
78 Duffy, 'A Rising Tide Lifts All Boats', Fortnight 461 (2008), 27-29, 28.

${ }^{79}$ Duffy, 'Rising Tide' 27.

${ }^{80}$ Arendt 9.

${ }^{81}$ Arendt 246.

${ }^{82}$ Arendt 178.

${ }^{83}$ Santner Everyday Life 10.

${ }^{84}$ Parker, Northern Star quoted in Lehner 48.

${ }^{85}$ Colm Tóibín, The Testament of Mary (London: Penguin/Viking, 2012), 72.
} 
painful for her. The pain further turns into radical indignation when the apostles ignore the vital care Jesus' father gave him and move the authority of truth to a metaphysical father figure: 'It was when they came to the last part that I stood up ... assaulted by their words. "He died to redeem the world ... His father sent him into the world that he might suffer on the cross"', 86

Finally, I like to point out that in this installation Duffy seems to offer a playful critique both on Arendt's philosophy and on political and religious bunting. First, Laundry Day in Derry illustrates that Arendt is wrong when she says that political activity 'goes on directly between men without the intermediary of things or matter' ${ }^{87}$ The strings of shirts are the intermediary, combining labour and work and political action in one installation. This, stretching from one end to the street to the other, connects all sides in society as all are affected by the economic problem of unemployment. Second, Duffy's multifarious shirts also seem to offer an alternative for the red pieces of cloth which, on Russian and Greek Orthodox icons, often connect houses. These red links may refer to a passage in the Apocalypse which mentions that the blood of the innocent lamb will set those people free who follow his peaceful course of action.

Instead, Duffy's street-linking shirts are multicoloured, sporting an invisible idea of sacrifice as it washes away the big (meta)physical (mi)stakes to let the wind celebrate the small physical daily sacrifice of women's time to their family. It is a glad and enabling care: the many different sizes and colours of the shirts will accommodate many 'newcomers' on the scene, children who relish the rainbow sight, new men who will do the laundry and women who will come up with new, refreshing models of life which will 'bestow upon human affairs faith and hope' $^{88}$

\footnotetext{
86 Tóibín 100.

87 Arendt 7.

${ }^{88}$ Arendt 247.
} 


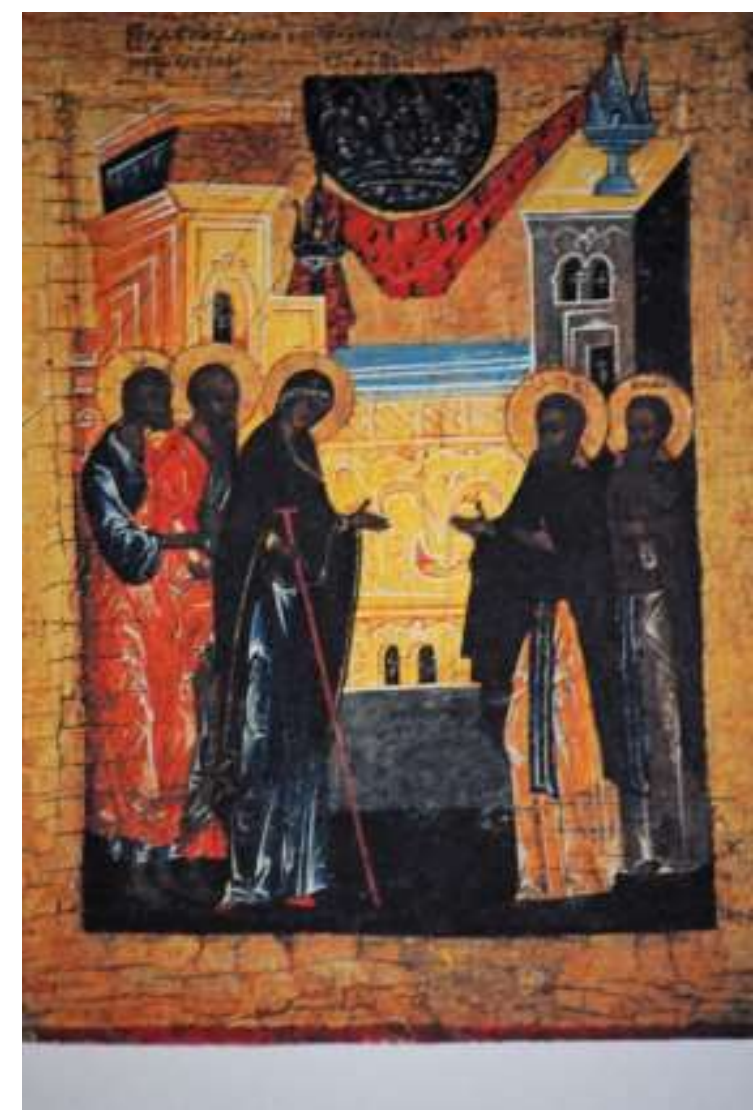

Crossroads Dancing (2015)

\section{Women of the world: transregional, transnational, transcontinental}

In Crossroads Dancing the artist's mother is again the central figure, and again an inclusive symbol par excellence. This inclusiveness is expressed in the colour scheme, the symbol of the dance and the references to labour and leisure. First, the mother marks the passage from green to orange as she dances over the path in white (softened by interaction with orange and green) in the foreground, moving easily from rural republican South to industrial North. But not only does the mother figure connect the colours on a horizontal axis (her leg in the green, her arm in the orange), she also does it on the vertical axis: from her orange hair via white blouse and green-orange skirt to orangey legs, she lives it all and fuses the realities of North and South. Moreover, the joyous dance seems to translate the stark colour scheme of the background into a much more interactive reality in the foreground, where the three colours are softened as they mix more. Second, the central woman integrates conscious and unconscious realities: connecting the (self)repressed (reputedly homo-erotic) arch-Catholic Padraic Pearse with her Northern man shows her openness to others, but this dance of life also allows her to integrate her own alter ego which takes part in the four-hand reel. And third, she combines labour and leisure, the active and the contemplative life.

That the workings of the imagination, the unconscious, are important is again indicated by the Chagall-like atmosphere: not only are there fiddlers and other musicians in all the colour fields, but the whole picture is built on simultaneity of different and often opposed images which is the watermark of the un- and preconscious. On the one hand there are the death drives, represented in De Valera's protectionist policies which drove his subjects out or literally into death, as depicted in the bed-ridden person in the left top corner. Yet on the 
other hand it seems the eros drives win: they are again central to the picture, in the dancing mother and reflecting on the girl on the right who is standing on a ladder, stretching to catch even more glow on her body. Crossroads Dancing seems in many ways to hark back to Awakening Tryptich I, II and III (drawn nineteen years earlier) as the punishing Catholicism of the nun chastising the girl in school uniform is again opposed to the dreamy, enabling mother; again we have a world teeming with genera, attractive images which catch the painter's imagination and set it aglow. ${ }^{89}$ But whereas in the Awakening Tryptich the life drives had a more outspoken erotic form in the phallic fish, the Dionysian forces are more varied here, in the male and female musicians, in the lady who is sunbathing in the orange glow. Being all part of a dreamlike world, these phantasms clearly sport their objet - objeu character, as they form a mental tool or toy to help the Duffy-like figure to relate to elements of her personal past, one in which the enabling maternal figure is central, once again.

\section{From The Shirt Factory to The Souvenir Shop (2016): Performing multidirectional memory}

While Rita Duffy's dancing mother shows a kind of vital elegance in making the transition from South to North the daughter follows in her (transborder) footsteps. Yet there is a widening of horizons: the artist moves not only easily between North and South but also between (Northern) Ireland and Europe and the rest of the world.

In 2016 Rita Duffy's ecumenical reputation brought her an invitation from the Arts Council of Ireland to contribute to one of the national projects in celebration of the 1916 Centenary events. She did so in her unique way with The Souvenir Shop, a travelling and therefore ever-changing installation where the complexities of the inviting community are treated with humour. The idea started in the 2013 Shirt Factory Project (cf supra) in Derry, then one of Europe's Culture Capitals. To allow the visitors to see their own culture at one remove Duffy translates typical objects of a culture into "objeux": toying with them she frees them from their original context so that they move from being a product of labour to being a product of work..$^{90}$ One example is the B Special Honey. Personally I was so charmed by the metaphor that I decided not to eat the honey, which meant the object lost its function leaving the sphere of 'labour'. As it became an object not for use but for meditation it entered the sphere of 'work'; more specifically it became a kind of poetry. Indeed, reconceiving the honey as she labeled it B special Honey the metaphor of the B/ee morphed a dark memory of Northern Ireland's past into a sweet present. Thus the same pot of honey moved from being a product of labour to work to interaction.

Considering the name of the installation, the Souvenir Shop, its interaction can further be specified with the help of political theory and memory studies. First, we see that Duffy's

\footnotetext{
${ }^{89}$ The nun seems to be holding a stick and thus of the punishing type; yet in her article 'Neither virgin nor whore' (1991) Duffy also refers to 'one old nun' who 'had a strange thread of feminism running through her philosophy'. This nun 'did spark ... that constant drive and ambition fed my confidence and my belief in my own capabilities' (3).

${ }^{90}$ Duffy taps here into the tradition of the ready-mades started by Marcel Duchamp, picked up by Op-and PopArt; when Duffy worked in New York she became familiar with those practices. Damien Hirst is a more contemporary exponent of this type of installation, but Duffy's art is more humorous and more political. These days installations like these raise questions about the relations between 'Site-specific Art and aesthetic autonomy'. Miwon Kwon has developed a 'viable typology of site-specific art' which distinguishes between phenomenological, institutional, and discursive site-specificity. Though this might apply in interesting ways to Duffy's travelling exhibition, these discussions are beyond the scope of this article.
} 
Souvenir works enable the practice of agonism that Chantal Mouffe calls for. As the opposite of antagonistic behaviour, it pleads for 'a relationship between political adversaries who share the same symbolic space and respect the democratic rules. ... agonism refers to the need to recognize emotions and passions [of all parties involved, victims and perpetrators] as an integral part of political confrontation while also giving them 'a democratic outlet' ${ }^{91}$ By turning the objects into objeux, tools for meditation, the humour creates a distance and gives people a positive space to rethink their coordinates, defusing the negative charges of the symbolic space and encouraging the Shop visitors to imagine the emotions of other parties than their own. Apart from the humour a second element is the 'cosmopolitan' nature of the memories celebrated in the Souvenir Shop: wherever the Souvenir Shop lands, it questions the local powers, those from the past (calling for World War One) as well of the present, such as the contemporary US, UK or EU administration. Each time the Souvenir objects highlight ambiguities and contradictions; like Pierre Nora, Duffy loves the 'polyphonic' approach he uses when he talks about 'les France' (Rothberg Noeuds 4). Indeed, in Duffy's 2016 version of The Souvenir Shop there are many (Northern) Irelands as the Shop sells objects referring to the Easter Rising as well as to the First World War, in which Rita's own grandfather from the Falls Road fell, in a British uniform. Yet, unlike his lieux de mémoire she dares highlight the noeuds de mémoire, as Rothberg puts it: history to Duffy is not glorious. Her Souvenir objects go against 'traditional teleological view[s] of history and memory ${ }^{92}$ and seems to follow Rothberg's suggestion of

a new model - or models - of remembrance. In calling for such a new approach under the sign of "noeuds de mémoire" - knots of memory - we hope to stimulate further conceptualization of collective or cultural memory beyond the framework of the imagined community of the nation-state. ${ }^{93}$

This is exactly what the Souvenir Shop does: it juxtaposes the lives of British soldiers and Easter casualties with French, Irish, Belgian and other nurses, thus realizing a cosmopolitan view, but one in which the common denominator is not heroism but co-suffering, not identitarian reduction' but compassion. ${ }^{94}$

Refusing 'antagonistic remembering', which "relies on heritage as monumentalism and on a canonical version of history [and]...on celebratory, glorifying or nostalgic narrative styles' Duffy's Shop debunks monuments, and questions and annotates canonical versions of history. ${ }^{95}$ For a start the name is again built on a pun - while Thomas Clarke ran a news agent's shop in Dublin, he really was a prime agent in making the news, as he was a leader in the Easter Rising. But Duffy's version of 1916 corrects past representations, restoring prominent women like Elizabeth Farrell into the picture; she helped negotiate the ceasefire in the GPO but was 'airbrushed out of the photograph in the National Museum collection'. Likewise the nurses who figure as bearers of compassion and care, sewing skin and clothes back together, get pride of place. Yet Rita Duffy is not the one who will build them marble statues, like Michelangelo's pieta. Instead the artist invited friends to craft small woollen dolls in the form

\footnotetext{
${ }^{91}$ Chantal Mouffe quoted in Bull and Hansen 393.

92 Michael Rothberg, 'Introduction: Between Memory and Memory: From Lieux de Mémoire to Noeuds de Mémoire', Yale French Studies 118/119 (2010): 3-12, 4.

${ }^{93}$ Rothberg, 'Noeuds' 7.

94 Rothberg, 'Noeuds' 7.

95 Bull and Hansen 391.
} 
of a pieta. Unlike T.S. Eliot who pictures how the women / Come and go, Talking of Michelangelo' Duffy's Souvenir Shop invites (wo)men to come and stay, wondering about Rita's way. As in previous works, the visitor must not expect an ode to metaphysical heroism but a questioning of the hero cult. ${ }^{96}$ Instead it is the victims and their co-sufferers, the mothers, who refuse nostalgia and celebration of power. What Duffy's humble objects do celebrate is the warmth and resilience, the unfailing support of humble women for their men, even when they became the innocent victims of an ideology.

\section{America and back: nomadic art extended (2017)}

Duffy's boundless interest in the human condition must have inspired the Mattress Factory Museum in Pittsburgh to invite this Northern Irish artist to come and visit in 2017, to work her magic on American concerns, so she applied her Souvenir Shop methodology in Trump territory. No doubt that president, would he ever see her work, would be pleased she used coal for her drawings. But she also turned objects into toys as she morphed his beloved weaponry into delft. However, in our textile context the 'you do good voodoo dolls' are central. Here the wigs of the Justus series are re-entering, except this time they are blond, and instead of floating on air they are now attached to a Trump head effigy. And again, the art work is interactional: those who visit the shop were encouraged to buy the dolls to do good voodoo with them. The fact that they were a roaring success indicates the people's hunger for change. ${ }^{97}$ So here we have another instance of agonistic memory, of which the 'main defining characteristics' are to be 'both reflexive and dialogic, yet also rel[ying] ... upon politicized representations of past conflicts, acknowledging civic and political passions as well as individual and collective agency" (Bull \& Hansen 390)

Throughout 2017 The Souvenir Shop travelled through the world while being enriched with a yet new transnational product, the Civil Rights and Dream Pillows. Once more Duffy elaborated the 'political' potential of shirt work, using the two-sidedness of a pillow to connect the local history of the forgotten (grand)mothers who worked in the textile industry in the North (celebrated in Jan Carson's Postcards in this issue) with the history of the AfricanAmerican Civil Rights Movement. In this sense Duffy's work realizes Rothberg's observation that

a radically democratic politics of memory needs to include a differentiated empirical history, moral solidarity with victims of diverse injustices, and an ethics of comparison that coordinates the asymmetrical claims of those victims' ${ }^{98}$

\footnotetext{
${ }^{96}$ Duffy's respect for the patient work and the horrifying sights that struck those nurses working in a support role of something they did not want (namely, war) converges with Mary's criticism in Tóibín's Testament of Mary: 'It is what really happened that is unimaginable, and it is what really happened that I must face now in the months before I go into my grave or else everything that happened will become a sweet story that will grow poisonous as bright berries that hang low on trees' (ToM 86). Tóibín's Mary even focuses on the figure of the pieta and describes the image as a mere wish-fulfilling dream: in her account neither the disciples nor she herself were brave enough to witness Jesus' cruel death till the end.

${ }^{97}$ In her article on Duffy's exhibition in Pittsburgh, Elaine King observes that this artist was chosen among other Northern Irish artists 'for their sensitivity to this volatile time of political and nationalistic conflict. Although the work here was not directly about the Troubles, it was nevertheless informed by suffering and pain' (74).

${ }^{98}$ Rothberg, 'Multidirectional' 526.
} 
Indeed the form of the cushion allows for different sides of the one object, images referring to 'diverse injustices' yet connected through common seams. But those cushions also have their agonistic dimension, reminding the buyer of a paradox which will make him personally uneasy, as the soft filling (one's comfort zone) contrasts with the cover which called for leaving that zone. Thus, these objects sport 'two important traits of cosmopolitan memory' as they are 'exposing the artificial nature of collective identities and promoting transnational memory practices' ${ }^{99}$ Yet, the transnational dimension only heightens the chances of solidarity, as Bull and Hansen observe:

We recognize the importance of transnational influence on local memory discourse and welcome the creation of collective feelings of solidarity. However, an agonistic mode of remembering, in addition to exposing the socially constructed nature of collective memory and including the suffering of the 'Others', would rely on a multiplicity of perspectives in order to bring to light the socio-political struggles of the past and reconstruct the historical context in ways which restore the importance of civic and political passions and address issues of individual and collective agency. ${ }^{100}$

While many theorists forget that cosmopolitan memory tends to be the luxury of the middle classes Bull \& Hansen and Mouffe do highlight the need to focus on social aspects. Indeed, Trump voters usually cannot count on much support from their educational system nor from other economic benefits, which locks them into the negative spiral of contemporary US politics. This is where the 'Shop' part of Rita Duffy's Souvenir Project comes in: people are supposed to actively, financially participate by buying and engaging with the multidirectional memories. But even in this difficult time there are pure signs of Arendt's 'natality' when students of the Marjory Stoneman Douglas high school shooting in Florida link up with others to demand the White House to protect children rather than guns, 'breaking the cycle' of violence endemic in the gun laws. ${ }^{101}$

\section{Soften the border (2017)}

Duffy's most recent project Soften the Border (2017) is another ecumenical political act in Arendt's sense of articulating singularity in interaction. The project invited people from both North and South as well as Irish travellers (a fine metaphor for Duffy's favourite image of 'passage') to express their views of the border in textile terms. All these 'cross-border women' together 'dressed' a bridge, festooning it in bright 'orbs of colour', thus co-creating a political statement with the beauty of a Sonja Delaunay painting. And again this installation is looking forward: instead of focusing on the dark sides of Brexit (a return of the dark past of this border) this communal artwork's perspective includes an appeal to be hospitable. And in Duffy's universal perspective, this means being open not only to direct neighbours (north or south) but also to refugees across Europe. In this sense, Duffy's most recent work does what it sets

\footnotetext{
99 Bull and Hansen 401.

100 Bull and Hansen 401.

101 <https://www.theguardian.com/us-news/2018/feb/19/donald-trump-background-checks-florida-shootingguncontrol?utm_source=esp\&utm_medium=Email\&utm_campaign=GU+Today+main+NEW+H+categories\&utm_te $\mathrm{rm}=264724 \&$ subid=14781483\&CMP=EMCNEWEML6619|2>.
} 
as a task for itself and its visitors: to open up to Otherness, to check on its own economy of life and death drives, and to be hospitable to visitors - a prime virtue in Irish culture.

\section{A rising tide lifts all the boats ${ }^{102}$}

As we looked at Rita Duffy's work between 1996 and 2017 her textiles, whether drawn, painted, sewn, crocheted, knitted or woven, alone or in a communal effort, they all together form a rich and consistent oeuvre, one in which resilient women take pride of place. Starting from paintings in which a Kahlo-like Duffy was not to be subdued by communal restrictions, we concluded with the Soften the Border installation, showcasing communal openings in the form of the dolls knitted by participants in the project from North and South as well as from the community of travellers. Acknowledging the paralyzing power of imitative behaviour and the negative energy of the aggressive architecture of her childhood Duffy calls for an 'All walls down!' encouraging people to reach out and 'overcome' sectarian divides. ${ }^{103}$ This means, in the first place, that the inside walls should come down: following the example of her resilient, imaginative mother Duffy calls for an exploration of the self, a development of one's traumas and phantasms, negative and positive images, to experiment with them in a disciplined kind of imagination which may yield ecumenical new blueprints for society.

In this idiom, Duffy often develops textile images: children are raised in 'habits' going from school uniforms to altar boy dress with lace (in the case of Muldoon); grenade skirts contrast with dance skirts; handkerchiefs become symbolic of vital kinds of passages, while laundered sheets form a road into a bright future. Anoraks and shirts worn by famous political figures, suspended in contextless air, ask the spectator to suspend his projections and change tack: unlike the relics of old, textiles of a famous origin do not heal because of their unambiguous origin but because of their otherness: they break projection and question the self. In each of her works, Duffy criticizes power, imitation, the cult of mortality with a belief in metaphysics; instead, she celebrates agency, radical questioning and natality, with a belief in the miracle of a radically new start in immanence. Instead of irony Duffy seems to prefer compassion, instead of rationality, charm, instead of walled-in communities, solidarity.

This remedial universe seemed to fit Arendt's categories of labour, work and political interaction, as these are three important dimensions of her own work. Duffy pleads for more initiatives by women in these politics of humour, creativity, leeway, openness. Art must create the necessary distance to bring people together while leaving them space; where feminine indirectness and practicality can overhaul destructive male aggression, where imitative culture can turn into a creative one, which allows for unicity in equality. Going by Duffy's use of colour, her art is getting richer every year but it also becomes more humorous, more layered, more humanity-embracing - we look forward to her next instalment of the Souvenir Shop.

\footnotetext{
102 This is the title of an article Rita Duffy published in Fortnight after her first year as President of the Royal Ulster Academy of Arts.

${ }^{103}$ Duffy 'All Walls down!', Fortnight 280 (1990): 10.
} 


\section{Works Cited}

Arendt, Hannah. The Human Condition, Second Edition, Introduction by Margaret Canovan. Chicago: University of Chicago Press, 1989.

Baert, Barbara. The gendered visage: facets of the Vera icon. Jaarboek van het Koninklijk Museum voor Schone Kunsten Antwerpen (2000), 10-43.

Barber, Fionna. 'An Iceberg's Collison with History: Some recent work by Rita Duffy'. The Essential Gesture. Recent Works by Rita Duffy. Catalogue, March 2005 n.p

Barber, Fionna. 'Rita Duffy's Unquiet Relics'. The Canadian Journal of Irish Studies 37.1-2 (2011): 36-47.

Bell, Vikki. 'The Poetry of Cloth: Painting, Potentiality and Politics'. Cloth. A Visual and Verbal Collaboration by Rita Duffy \& Paul Muldoon. Portadown: Millennium Court Arts Centre, 2007. 8.

Bollas, Christopher. The Shadow of the Object. Psychoanalysis of the Unthought Known. New York: Columbia University Press, 1987.

Bollas, Christopher. The Mystery of Things. London: Routledge, 1999.

Bollas, Christopher. The Evocative Object World. London: Routledge, 2009.

Bollas, Christopher. The Christopher Bollas Reader. Introduction by Arne Jemstedt. Foreword by Adam Phillips. London/New York: Routledge, 2011.

Bull, Anna Cento and Hans Lauge Hansen. 'On agonistic memory'. Memory Studies 9:4 (2016): 390-404.

Caruth, Cathy. 'Introduction.' Trauma, Explorations in memory. Ed. Cathy Caruth. Baltimore/London: The Johns Hopkins University Press, 1995. 3-12.

Dalsimer, Adele, and Vera Kreilkamp. 'Stepping Out: Reading Rita Duffy's Dancer.' Éire-Ireland 32.2 (1997): 208-217.

Duffy, Rita. 'All Walls down!' Fortnight 280 (1990): 10.

Duffy, Rita. 'Neither Virgin nor Whore' Fortnight 292 (1991): 3.

Duffy, Rita. Banquet. Catalogue to the exhibition in Ormeau Baths Gallery Belfast 28 August 20 September 1997 and Hugh Lane Gallery Dublin, 12 February-5 April 1998.

Duffy, Rita. The Essential Gesture. Recent Works by Rita Duffy. Catalogue, March 2005 n.p.

Duffy, Rita. Cloth. A Visual and Verbal Collaboration by Rita Duffy \& Paul Muldoon. Portadown: Millennium Court Arts Centre, 2007.

Duffy, Rita. 'Cloth'. Review of Irish Studies in Europe 2.1 (2018): 46-56.

Duffy, Rita. 'A Rising Tide Lifts All Boats.' Fortnight 461 (2008): 27-29.

Enright, Anne. The Gathering. London: Jonathan Cape, 2007.

Ettinger, Bracha L. The Matrixial Borderspace. Minneapolis/London: University of Minnesota Press, 2006. (Series: Theory out of Bounds 28).

Evans, Dylan. An Introductory Dictionary of Lacanian Psychoanalysis. Hove \& New York: Brunner-Routledge, 1996.

Foxes. Directed by Lorcan Finnegan. <https://vimeo.com/83593404>.

Gaiger, Jason. 'Dismantling the Frame: Site-Specific Art and Aesthetic Autonomy'. The British Journal of Aesthetics, 49.1 (2009): 43-58.

Girard, René. The Scapegoat. Translated by Yvonne Freccero. Baltimore: the John Hopkins University Press, 1989.

Hutchinson, Wesley. 'Rita Duffy, Variations on the Theme of Separation.' Etudes irlandaises 30.1 (2005). 193-201. 
Johnston, Megan. 'Interrogating Contested Spaces in Post-Conflict Society. Collaboration in Verbal and Visual'. Cloth. A Visual and Verbal Collaboration by Rita Duffy \& Paul Muldoon. Portadown: Millennium Court Arts Centre, 2007. 3.

Joyce, James. Portrait of the Artist As a Young Man. Ware: Wordsworth Classics, 1992.

Kilroy, Claire. The Devil I Know. London: Faber \& Faber, 2012.

King, Elaine. 'Mattress Factory.' Sculpture 36.8 (2017): 74-76.

Lehner, Stefanie. 'Performing Belfast: Stewart Parker's Northern Star (1984) and Pentecost (1987)'. Boundaries, Passages, Transitions. Essays in Irish Literature, Culture and Politics in Honour of Werner Huber. Ed. Hedwig Schwall. Trier: Wissenschaftlicher Verlag Trier, 2018; 41-52.

Morrissey, Sinéad. Between Here and There. Manchester: Carcanet, 2002.

Moyaert, Paul. 'The Death Drive and the Nucleus of the Ego. An Introduction to Freudian Metaphysics'. The Southern Journal of Philosophy, Spindel Supplement 51 (2013): 94 $-119$.

Muldoon, Paul. 'Anseo.' Poems 1968-1998. London: Faber and Faber, 2001. 83-84.

Rilke, Rainer Maria. The Notebooks of Malte Laurids Brigge. A novel. Trans. Stephen Mitchell. With introduction by William H. Gass. New York: Vintage International, 1990.

Rothberg, Michael. 'From Gaza to Warsaw: Mapping Multidirectional Memory'. Criticism 53.4 (2011): 523-48.

Rothberg, Michael. 'Introduction: Between Memory and Memory: From Lieux de Mémoire to Noeuds de Mémoire'. Yale French Studies 118/119 (2010): 3-12.

Ryan, Donal. The Spinning Heart. London: Doubleday Ireland, 2012.

Santner, Eric. The Royal Remains. The People's Two Bodies and the Endgames of Sovereignty. Chicago and London: The University of Chicago Press, 2011.

Santner, Eric. On the Psychotheology of Everyday Life. Reflections on Freud and Rosenzweig. Chicago: Chicago University Press, 2001.

Schwall, Hedwig. 'Muscular Metaphors in Anne Enright: An Interview'. The European English Messenger 17.1 (Spring 2008): 16-22.

Schwall, Hedwig. 'Towards a new grammar of interiority: James Ramsay's circuitous way To the Lighthouse'. Grammar, usage and discourse. Eds. Lieven Vandelanotte, Wout Van Praet and Lieselotte Brems. English Text Construction 10:2 (2017), 323-344.

'Students stage White House protest as Trump gives nod to background bill'. The Guardian, 19 February 2018. <https://www.theguardian.com/us-news/2018/feb/19/donaldtrump-background-checks-florida-shooting-gun-

control?utm_source=esp\&utm_medium $=$ Email\&utm_campaign $=\mathrm{GU}+$ Today + main $+\mathrm{NEW}+\mathrm{H}+\mathrm{C}$ ategories\&utm_term $=264724 \&$ subid $=14781483 \& C M P=E M C N E W E M L 6619 \mid 2 />$. Accessed 20 February 2018.

Tóibín, Colm. The Testament of Mary. London: Penguin/Viking, 2012.

van Os, Henk. Gebed in schoonheid. Schatten van privé-devotie in Europa 1300-1500. Tentoonstelling Rijksmuseum Amsterdam. November 1994 - Februari 1995. Amsterdam/London: Rijksmuseum/Merrell Hoberton, 1994.

Winnicott, D.W. Playing and Reality. New York: Routledge, 1989.

Yeats, W.B. 'September 1913'. The Collected Poems of W.B. Yeats. London and Basingstoke: Macmillan, 1981.

Yeats, W.B. 'Per Amica Silentia Lunae'. Mythologies. New York: Macmillan/Collier Books, 1969. 